\title{
Examining potential benefits and challenges associated with the Internet of Things integration in supply chains
}

\author{
Abubaker Haddud \\ College of Technology, Eastern Michigan University, Ypsilanti, Michigan, USA \\ Arthur DeSouza \\ Salford Business School, The University of Salford, Manchester, UK \\ Anshuman Khare \\ Faculty of Business, Athabasca University, Edmonton, Canada, and \\ Huei Lee \\ College of Business, Eastern Michigan University, Ypsilanti, Michigan, USA
}

\begin{abstract}
Purpose (mandatory) - The Internet of Things (IoT) is expected to have a huge impact on businesses and, especially, the way we think about supply chain management. However, there is still a paucity of studies on the impact of IoT adoption on supply chains and on different aspects of the business in general. The research aims to examine the impact of adoption of Internet of Things (IoT) in organizational supply chains with a view to verify potential key benefits and challenges existent in the literature. The research presents the impact on an organization along with the impact across its entire supply chain.

Design/methodology/approach (mandatory) - Data was collected through the use of an online survey and 87 participants completed the survey. Participants were mainly university scholars based in different countries located in six continents. Participants were authors, or co-authors, of academic papers published in the Decision Science Institute 2015 and 2016 annual conference proceedings, the 21st International Symposium of Sustainable Transport \& Supply Chain Innovations, the Supply Chain Management: An International Journal 2016 issues, and the Operations and Supply Chain Management: An International Journal 2016 issues.

Findings (mandatory) - We were able to confirm the significance of some of the examined potential benefits to individual organizations and their entire supply chains. However, the study identified other potential benefits that were not seen as a direct impact of IoT adoption. Most of the examined potential benefits were found to contribute to a number of critical success factors for implementing successful supply chain management. We were also able to confirm that some of the examined potential challenges were still perceived as key hinders to IoT adoption but examined potential challenges were not seen as hurdles to IoT adoption.

Originality/value (mandatory) - To our best knowledge, this is the first study of its kind. Although some literature attempted to provide an overview about the IoT management, no study has specifically explored potential benefits and challenges related to the adoption of IoT in supply chains and ranked them based on their significance. The results can be beneficial to; academic scholars interested in the researched topic, business professionals, organizations within different sectors, and any other party interested in understanding more about the impact of adopting IoT on supply chain management.
\end{abstract}

Keywords Internet of Things, IoT, supply chain management, benefits, risks, challenges, technology, adoption.

Paper type Research paper 


\section{Introduction}

The Internet of Things (IoT) as a term has been around for about 20 years and it first appeared in 1999 . The term was coined in the context of supply chain management by Kevin Ashton who was working on a research project at the Massachusetts Institute of Technology's (MIT) AutoID lab to explore ways to improve business performance through linking the Radio Frequency Identification (RFID) technology information to the Internet (Gubbi et al., 2013). There is no common definition for the IoT but it simply relates to the integration of physical objects communicating with one another and through the Internet to achieve some useful objectives (Botta et al., 2016; Whitmore et al., 2014; and Wortmann and Flüchter, 2015). IoT facilitates a safe and trustworthy way of exchanging information related to goods and services in a global supply chain (Mishra et al., 2016). IoT will be less a revolution than a valuable (and welcome) evolution that will contribute to the next wave of productivity gains driven by information technology transformation (Behrendt et al., 2017). Kumar et al. (2015) identified 13 critical success factors, based on an extensive literature review of 66 journal articles, for successful implementation of supply chain management that include: top management commitment; development of effective supply chain management strategy; devoted resources for supply chain; logistics synchronization; use of modern technologies; information sharing with supply chain members; forecasting of demand on point-of-sale (POS); trust development in supply chain partners; developing Just-in-time capabilities; development of reliable suppliers; higher flexibility in production system; focus on core strengths; and long-term vision for survival and growth. Our study shows how these success factors are impacted by the adoption of IoT.

The Internet of Things is believed to bring tangible business benefits (Borgia, 2014; Madakam et al., 2015 and Russo et al., 2015). The adoption of the IoT has the potential to improve operational processes, reduce costs and risks due to its transparency, traceability, adaptability, scalability, and flexibility (Zhou et al., 2015). However, the challenges facing the emergence of the IoT are numerous (technical and social) and these challenges must be overcome in order to ensure effective IoT adoption and diffusion (Whitmore et al., 2015). Lee and Lee (2015) state that there is still a paucity of studies on the social, behavioral, economic, and managerial aspects of the IoT. This makes it very challenging for companies to make informed decisions as regards IoT adoption/ implementation. Mishra et al. (2016) state that there are limited, if any, studies that look into the relationship between IoT adoption and the increase of organizational and supply chain performance. The same reference adds that the adoption process and the enablers, drivers, barriers, and models of IoT adoption by organizations and supply chain should be explored. Whitmore et al., (2015) concluded that IoT is not well-represented in the management literature and it is dominated by research relating to IoT technologies.

The IoT has opened up a completely new set of opportunities for research and practice in SCM $(\mathrm{Ng}$ et al., 2015). Mishra et al. (2016) proposed four future potential research themes two of which were directly related to IoT adoption in supply chains as follows: 'What are the drivers and barriers of IoT implementation and adoption?'; 'How can we explain IoT implementation and adoption using alternative organizational theories?; 'How can we measure the impacts of IoT on organizational and supply chain performance?; and 'Can we propose a holistic model that explains the acceptance of IoT applications?'

The purpose of this paper is to empirically examine the impact of IoT adoption on individual organizations and their entire supply chains. More specifically, the study attempts to answer the following two main research questions: 
RQ1. What are the potential benefits organizations, and their entire supply chains, that are likely to gain from the adoption of IoT?

RQ2. What are possible challenges organizations, and their entire supply chains, that are likely to face when adopting IoT?

There are five sections in this paper. Section 1 introduces the topic, research motivation, and purpose of the research. Section 2 reviews relevant literature on IoT overview, digital supply chain, and IoT in supply chains. Section 3 describes the used research methodology, including instrument development, sample and data collection, participants profile, data analysis methods, and instrument reliability and validity testing. Section 4 presents data analysis and the study results. The final section discusses the conclusions, implications of the findings, and limitations and future research.

\section{Literature review}

\subsection{Overview of the Internet of Things}

IoT can be understood as a combination of three main elements; web-based (middle-ware), things-based (e.g. sensors), and semantic-based (knowledge) (Chandrakanth et al., 2014). Botta et al. (2016) defined IoT as intelligent and self-configuring nodes (things) interconnected in a dynamic and global network infrastructure. It represents one of the most disruptive technology, enabling ubiquitous and pervasive computing scenarios. The IoT can also be defined as a network of hardware, software, devices, databases, objects, sensors, and systems, all working at the service of humanity (Wu et al., 2016). A foundational technology for the IoT is the RFID technology, which allows microchips to transmit the identification information to a reader through wireless communication (Da Xu et al., 2014). The IoT enables physical objects to see, hear, think and perform jobs by having them "talk" together, to share information and to coordinate decisions. These physical objects become smart by using underlying technologies such as ubiquitous and pervasive computing, embedded devices, communication technologies, sensor networks, Internet protocols and applications (Al-Fuqaha et al., 2016). Gartner identifies the top 10 Internet of Things technologies for 2017 and 2018 (Gartner Press Release, 2016). See Table 1 for details:

Table 1 Top 10 Internet of Things technologies for 2017 and 2018 (Gartner Press Release, 2016)

\begin{tabular}{|c|c|}
\hline Technology & Description \\
\hline - loT Security & $\begin{array}{l}\text { Security technologies will be required to protect loT devices and platforms from both } \\
\text { information attacks and physical tampering. }\end{array}$ \\
\hline - IoT Analytics & $\begin{array}{l}\text { New analytic tools and algorithms are needed now, but as data volumes increase through } 2021 \text {, } \\
\text { the needs of the loT may diverge further from traditional analytics. }\end{array}$ \\
\hline $\begin{array}{l}\text { - loT Device (Thing) } \\
\text { Management }\end{array}$ & $\begin{array}{l}\text { The loT also brings new problems of scale to the management task. Tools must be capable of } \\
\text { managing and monitoring thousands and perhaps even millions of devices. }\end{array}$ \\
\hline $\begin{array}{l}\text { - Short-Range loT } \\
\text { Networks }\end{array}$ & $\begin{array}{l}\text { Low-power, short-range networks will dominate wireless loT connectivity through 2025, far } \\
\text { outnumbering connections using wide-area loT networks. }\end{array}$ \\
\hline - Wide-Area Networks & $\begin{array}{l}\text { The long-term goal of a wide-area loT network is to deliver data rates from hundreds of bits per } \\
\text { second (bps) to tens of kilobits per second (kbps) with nationwide coverage, a battery life of up } \\
\text { to } 10 \text { years, an endpoint hardware cost of around } \$ 5 \text {, and support for hundreds of thousands of } \\
\text { devices connected to a base station or its equivalent. }\end{array}$ \\
\hline - $\quad$ loT Processors & $\begin{array}{l}\text { The processors and architectures used by loT devices define many of their capabilities, such as } \\
\text { whether they are capable of strong security and encryption, power consumption, whether they } \\
\text { are sophisticated enough to support an operating system, updatable firmware, and embedded }\end{array}$ \\
\hline
\end{tabular}


device management agents.

- loT Operating A wide range of IoT-specific operating systems has been developed to suit many different Systems

- Event Stream Processing hardware footprints and feature needs.

Processing

Distributed stream computing platforms (DSCPs) have emerged. They typically use parallel architectures to process very high-rate data streams to perform tasks such as real-time analytics and pattern identification.

- IoT Platforms loT platforms bundle many of the infrastructure components of an loT system into a single product; (1) low-level device control and operations; (2) loT data acquisition, transformation and management; and (3) loT application development.

- IoT Standards and Standards and their associated application programming interfaces (APIs) will be essential Ecosystems because loT devices will need to interoperate and communicate, and many loT business models will rely on sharing data between multiple devices and organizations.

The adoption of IoT continues to expand and it is expected to have an enormous impact on consumers, businesses and society as a whole. The worldwide IoT solutions market is expected to grow from US\$ 1.9 trillion in 2013 to US\$ 7.1 trillion in 2020, and the number of installed base of IoT units is expected to achieve 28.1 billion in 2020 (Lund et al., 2014). It is also predicted that more than half of major new business processes and systems will incorporate some element of the Internet of Things (IoT) by 2020 (Gartner, Inc., 2016). IoT adoption is expected to continue to grow in; logistics (supply chains and warehousing), retailing, manufacturing, healthcare, energy and utilities, home appliances, heavy equipment, education, insurance, airlines, etc. (Gregory, 2015; Kambies et al., 2016; Lee and Lee, 2015; Maksimović et al., 2015; and Natarajan et al., 2016). Overall, IoT applications can be categorized into four major domains: Industry domain; Healthcare domain; Smart environments domain; and Personal and Social domain (Mishra et al., 2016). Table 2 presents IoT applications/benefits to the previously identified sectors:

Table 2 loT adoption benefits within several sectors

\begin{tabular}{|c|c|}
\hline Sector & IoT applications/benefits \\
\hline - Logistics & $\begin{array}{l}\text { Constructing a seamlessly integrated environment, enhancing the scalability, configurability, } \\
\text { and extendibility of the production system, facilitating autonomous agent-based local } \\
\text { collaboration, and promoting quick rescheduling and planning in production logistics (Yu, } \\
\text { 2016). }\end{array}$ \\
\hline - Retailing & $\begin{array}{l}\text { Automated checkouts, better inventory management, store layout optimization, customer } \\
\text { tracking, item location identification, on-shelf availability, real-time in-store promotions, } \\
\text { augmented reality, and smart customer service (Bok, 2016). }\end{array}$ \\
\hline - Manufacturing & $\begin{array}{l}\text { Improved processes, self-optimization, autonomous decision-making, decentralized supply } \\
\text { chains, more connections of manufacturing processes, smart products, individualized } \\
\text { distribution and procurement, and better monitoring and control of physical processes } \\
\text { (Roblek et al., 2016). }\end{array}$ \\
\hline - Healthcare & $\begin{array}{l}\text { Clinical care, remote monitoring, and early intervention/prevention (Kulkarni and Sathe, } \\
\text { 2014). }\end{array}$ \\
\hline $\begin{array}{l}\text { - Energy and } \\
\text { utilities }\end{array}$ & $\begin{array}{l}\text { Streamlines information flow, heightened asset performance, mitigated supply chain risks, } \\
\text { product quality and consistency, energy management, smart thermostat, etc. (Kyriazis et al., } \\
\text { 2013; Moreno et al., 2014; SAP Corporation, 2014; and Zheng and Carter, 2015). }\end{array}$ \\
\hline $\begin{array}{l}\text { - Home } \\
\text { appliances }\end{array}$ & $\begin{array}{l}\text { Energy consumption management, interaction with appliances, detecting emergencies, } \\
\text { home safety and finding things easily, home security etc. (Khan et al., 2012). }\end{array}$ \\
\hline $\begin{array}{l}\text { - Heavy } \\
\text { equipment }\end{array}$ & Assets monitoring, traceability and tracking (Velandia et al., 2016). \\
\hline - Education: & New educations systems, more empowered (digital) students, new ways of instruction, etc. \\
\hline
\end{tabular}


(Agrawal and Mazumdar, 2015; Selinger et al., 2013).

- Insurance Establish direct, unmediated customer relationships, individualize offerings of products, features and access options (Koenig et al., 2016).

- Airlines Better luggage management, better booking services, improved passengers' navigation in airports, better airport parking management, etc. (Alghadeir and Al-Sakran, 2016).

The adoption of IoT solutions can yield more transparency and visibility of information and materials flow within business processes. This result supports the theoretical benefits pointed on several studies regarding the importance of accuracy and availability of real time information and the operations transactions along forward and reverse movement of physical goods in both services and manufacturing industry (Sun, 2012; Ting et al., 2010; Xu et al., 2012; Reaidy et al., 2014; Kumar et al., 2016). Another key potential benefit businesses can obtain from implementing the IoT is the improvement in products tracking and tractability (Costa et al., 2012; Cao et al., 2013; Uddin and Sharif, 2016). Other potential benefits may include: better inventory management and control (Fan et al., 2015; Reaidy et al., 2015; Thiesse and Buckel, 2015), improved integration levels of internal business processes (Mann, 2015), enables a strategic redesign of all operations business processes in integrated fashion to enable operational performance improvements (Ferreti and Schiavone, 2016), and improved operational efficiency as a whole ( $\mathrm{Li}$ and $\mathrm{Li}, 2017$ ). This study will examine 35 potential benefits a business and its entire supply chain many gain from the adoption of IoT related solutions. The significance of each benefit will be identified and overall ranking will be provided.

\subsection{Digital Supply chain}

The digital supply chain (DSC) can be defined as the strategic and operative exchange of information (financial, production, design, research, and/or competition) between members of the chain to enhance communications (Korpela et al., 2017). The digital supply chain consists of eight key elements: integrated planning and execution, logistics visibility, procurement 4.0, smart warehousing, efficient spare parts management, autonomous and B2C logistics, prescriptive supply chain analytics, and digital supply chain enablers (Schrauf and Berttram, 2016). Digital supply chains enable business process automation, organizational flexibility, and digital management of corporate assets (Chase, 2016). The goal of the digital supply chain is ambitious: to build an altogether new kind of supply network that's both resilient and responsive (Schrauf and Berttram, 2016). Meier (2016) identified eight digital technology trends in supply chain management [see Table 3] and provided brief descriptions about what each one provides to the business.

Table 3 Digital technology trends in supply chain management (Meier, 2016, p. 235)

\begin{tabular}{lll}
\hline Digital technology trend & Functions \\
\hline - Mobility & Mobile applications for performing business processes at any time and any place \\
- Big and Smarter Data & $\begin{array}{l}\text { (Near) live analysis of large volumes of structured and non-structured data to get } \\
\text { deeper insights and enable reliable decision making }\end{array}$ \\
- Cloud Computing & $\begin{array}{l}\text { Internet-based IT infrastructure to enable collaborative processes and scalable Total } \\
\text { Cost of Ownership (TCO) }\end{array}$ \\
- Social Media & $\begin{array}{l}\text { Private and business oriented networks for communication and collaboration } \\
\text { purposes to be leveraged as additional data sources and sinks }\end{array}$ \\
- Predictive and & Analysis of structured and non-structured data and recognition of specific patterns
\end{tabular}


Prescriptive Analytics (through usage of advanced algorithms) to enable more precise predictions of future behaviors.

- Internet of Things Seamless integration of physical objects (e.g. machines with sensors, labor, etc.) into the information network to make use of high amount of additional data.

- 3D Printing and Mass customization of different types of products to most individual customer Scanning needs.

- Robotics

Machines with appropriate intelligence to perform specific processes faster, cheaper, safer and better quality results.

The digital revolution has affected all aspects of business including supply chains (Chase, 2016). Supply chain management (SCM), as a key business priority present within almost every manufacturing company's strategy, finds itself in the center of this upcoming digital era, where almost everything will be connected to almost everything via the Internet (Farahani et al., 2017). In a study on the rise of Industry 4.0 conducted by $\mathrm{PwC}$, more than third of more than 2,000 respondents say their companies have started to digitize their supply chains and 72 percent expect to have done so in five years (Schrauf and Berttram, 2016). The digitalization will become one of the major research topics for the supply chain management community in the future (Pflaum et al., 2017). Recent developments concerning digitalization are expected to play an increasingly significant role in the management and design of global supply chains (Klötzer and Pflaum, 2017). Based on the review in this section, it is evident that understanding potential implications of digitizing supply chains is crucial. Our study explores the impact of IoT adoption on supply chain management, and this is one of the key aforementioned digital technology trends. A number of key potential benefits businesses, and their supply chains, would gain as a result of IoT implementation will be examined, and their importance will be categorized/ranked; thus, the study fulfills this research need/gap.

\subsection{IoT and supply chain management}

Supply chain integration is important in improving business performance. This can be achieved through reducing cost, improving responsiveness, increasing service level, and facilitating decision making. Information sharing and collaboration as well as the agility are the key characteristics of the supply chain integration (Yan et al., 2014). From a supply chain management perspective, the IoT may allow machineenabled decision making with minimum or no human intervention. It deals with integrating and enabling information communication technologies including RFID, wireless sensor networks, machine-to-machine systems, mobile apps, etc. (Zhou et al., 2015). The IoT use in supply chains could bring visibility to each individual item, generating a highly visible supply chain, where the location and characteristics of all the things in the supply chain could be ascertained at any point in time (Geerts and O'Leary, 2014). Within the supply chain, IoT usage leads to an increase in profits, a reduction in excess product that quickly loses value, faster response to changing client needs or supplier availability, and more optimization of shipments and the assurance of complete deliveries (Robinson, 2015). The supply chains that respond and adjust to this fast IoT growth will achieve greater benefits and more competitive advantages in the new business environment ( $\mathrm{Li}$ and $\mathrm{Li}, 2017$ ). The IoT adoption will make businesses act in a predictive manner instead of reacting to the challenges of a complex and volatile market. This will help them significantly improve operational performance through an effective management of production levels. This will also result in a more efficient delivery of services and products to the market easing the common constraints of unpredictable demand and supply disruptions. 
Companies need to embrace such IoT solutions in a smart manner to incorporate these technologies that sustain more effective supply chains. Most companies fail due to poor integrations of technology in their supply chain (Majeed and Rupasinghe, 2017). There are many challenges and barriers that can be encountered when adopting the IoT. Some of these included in the literature are: businesses still do not comprehend the potential gains they may obtain from the adoption of IoT and this acts as the reason why many enterprises have not decided to embrace it yet (Da Xu et al., 2014; Lee and Lee, 2015; Ryan and Watson, 2017). Challenges with obtaining the access to employees who possess the required knowledge and skills remain another key factor hindering the IoT adoption (Hung, 2016; Petel et al., 2017; Ryan and Watson, 2017). In addition, incorporating new technologies into existent business environments, structures, and models has always been a challenge. This also remains the case when the IoT is implemented (Dijkman et al., 2015; Hognelid and Kalling, 2015; Pfisterer et al., 2016). Other challenges may be linked with internal and external technological integration (Da Xu et al., 2014; Buntz, 2015; Gnimpieba et al., 2015; Hussain, 2016; Valmohammadi, 2016; Bröring et al., 2017). As mentioned earlier, the adoption of IoT related technologies and applications is still in its infancy stage and developing global governing standards remains an issue and a hurdle to a wider implementation of IoT (Fang et al., 2014; Tao et al., 2014; Riggins and Wamba; 2015; Tan and Koo, 2014). Other barriers to the adoption of IoT is the risks and variabilities that may arise from such use of ecosystems (Lee and Lee, 2015; Reaidy et al., 2015; Riggins and Wamba, 2015; Martellini et al., 2017). Finally, many businesses simply are not ready for such a change. They lack the required architecture (objects, networks, data services, etc.) (Bi et al., 2014; Jin et al., 2014; Bughin et al., 2015; Li et al., 2015). Our research examines 30 potential challenges businesses, and their supply chains, may face when embracing the IoT.

Based on the review of literature on IoT, digital supply chains, and integration of IoT in supply chains; a conceptual model can be created to portray the impact of IoT adoption on organizations and their supply chains (see Figure 1). Our study examines potential benefits and challenges associated with the IoT adoption within supply chains and the results would help organizations respond and adjust quicker to the IoT growth and achieve greater competitive advantages.

Figure 1 Research framework

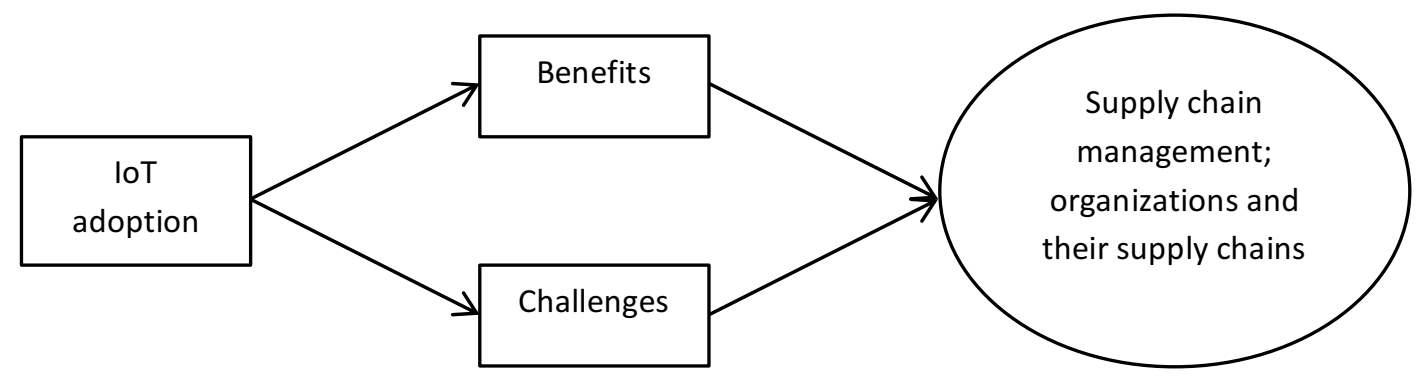

\section{Research Methodology}

\subsection{Instrument development}


The primary data for this research was collected through the use of an online survey. To our best knowledge, there was no similar developed and used instrument by other studies in the past. Thus, the design of this survey was primarily based on information extracted from the available literature to form meaningful, and relevant, statements. The survey consisted of four main parts in addition to The General Information part. The General Information section consist of four main questions including; the participants' field and area of expertise; years of experience in their current field; their level of knowledge of the IoT; and their geographical location. The participants were asked to share their perception by rating their responses on a five-point level of agreement Likert scale to answer the statements included under the four main parts of the survey. Part 01 included 17 potential benefits individual organizations may gain when adopting the IoT. 17 related statements were used in the survey as shown in Table 6. Part 02 included 18 possible benefits the entire supply chain network gain when IoT is adopted across the chain as shown in Table 7. Part 03 consisted of 15 potential risks individual organizations may face when adopting the IoT as presented in Table 8. Part 04 consisted of 15 possible challenges and risks that the entire supply chain network may encounter when implementing the IoT as shown in Table 9.

\subsection{Sample and data collection}

The data for this research was collected during February and March 2017 through a web-based survey developed on the QuestionPro online platform. The authors identified two potential sources of primary data for this study; 1) practitioners who have direct involvement with IoT implementation, and 2) academics who specialize in areas related to this technology. Although it would be more useful to gain insights from practitioners, it was not possible to get access to a good sample size from this group who are located in different global areas to avoid the results been interpreted as biased. Thus, a decision has been made to target the second group. The selected participants were either authors or co-authors of academic papers on three international conference proceedings and two international academic journals from operations and supply chain management discipline. The participation email invitation was initially sent to 641 individuals who published or co-published articles in the Decision Science Institute 2015 and 2016 annual conference proceedings and the 21st International Symposium of Sustainable Transport \& Supply Chain Innovations. A second invitation was sent to 104 individuals who either published or copublished journal articles in 2016 issues of the Supply Chain Management: An International Journal and the Operations and Supply Chain Management: An International Journal. In total, email invitations were sent to 745 participants, 239 viewed the survey, 124 started completing it, and 87 fully completed surveys were received resulting in a response rate of 11.67 percent. Out of the 87 fully completed the survey, 73 were from those who presented at the selected conferences and 14 from those who published at the two selected SCM journals. More specifically, 11.38 percent of the participants selected from the identified conferences completed the survey and 13.46 percent of the participants from the second group fully completed the survey. As it can be seen, the response rate was closely similar from the two targeted groups; thus, it was not possible to infer some observations about which of the two groups should yield better response rates should they be targeted in future studies.

\subsection{Profile of participants}

The profile of participants in this study is provided in Table 4. The participants' responses indicate that 39.08 percent had supply chain management expertise. 14.94 percent indicated their field as operations management, 11.49 percent stated business and management as their main area of expertise, 11.49 
percent had a technology management background, and 22.98 percent indicated other areas of expertise e.g. production management, service management, strategic management, and management of information systems. Table 4 shows that 25.28 percent of the participants had 1-5 years of work experience in their current field, 21.83 percent had 6-10 years, 26.43 percent had 11-20, and a similar percent of 26.43 had 21 years or more. As regards the knowledge of the IoT, almost 60 percent of participants heard or read about the topic, 20.68 percent worked on projects or research involving IoT aspects, 12.64 percent teach IoT topics or modules, and only 0.06 percent stated that this was the first time to hear about the topic. With regards to where participants were physically located (see Figure 2), 41.37 percent were in North America (the United States of America), 32.18 percent in Asia, 16.9 percent in Europe, and 0.11 percent were based in South America, Africa, and Australia (see Figure 2 for more details).

Table 4 Profile of participants

\begin{tabular}{|c|c|c|}
\hline Question & $\begin{array}{l}\text { Frequency } \\
(n=87)\end{array}$ & Percentage \\
\hline \multicolumn{3}{|l|}{ Field and main area of expertise } \\
\hline - Supply Chain Management & 34 & 39.08 \\
\hline - Operations Management & 13 & 14.94 \\
\hline - Business and Management & 10 & 11.49 \\
\hline - Technology Management & 10 & 11.49 \\
\hline - Other & 20 & 22.98 \\
\hline \multicolumn{3}{|l|}{ Years of experience in current field } \\
\hline - $1-5$ & 22 & 25.28 \\
\hline - $6-10$ & 19 & 21.83 \\
\hline - $\quad 11-20$ & 23 & 26.43 \\
\hline - $21+$ & 23 & 26.43 \\
\hline \multicolumn{3}{|l|}{ Knowledge of the Internet of Things } \\
\hline - Worked on projects/research involving loT aspects & 18 & 20.68 \\
\hline - Teach loT topics/modules & 11 & 12.64 \\
\hline - Heard/read about the topic & 52 & 59.77 \\
\hline - This is the first time to learn about the topic & 6 & 0.06 \\
\hline \multicolumn{3}{|l|}{ Geographical location } \\
\hline - North America & 36 & 41.37 \\
\hline - Asia & 28 & 32.18 \\
\hline - Europe & 14 & 16.09 \\
\hline - Africa & 4 & 0.04 \\
\hline - South America & 4 & 0.04 \\
\hline - Australia & 3 & 0.03 \\
\hline
\end{tabular}

Figure 2 Participants' geographical location 


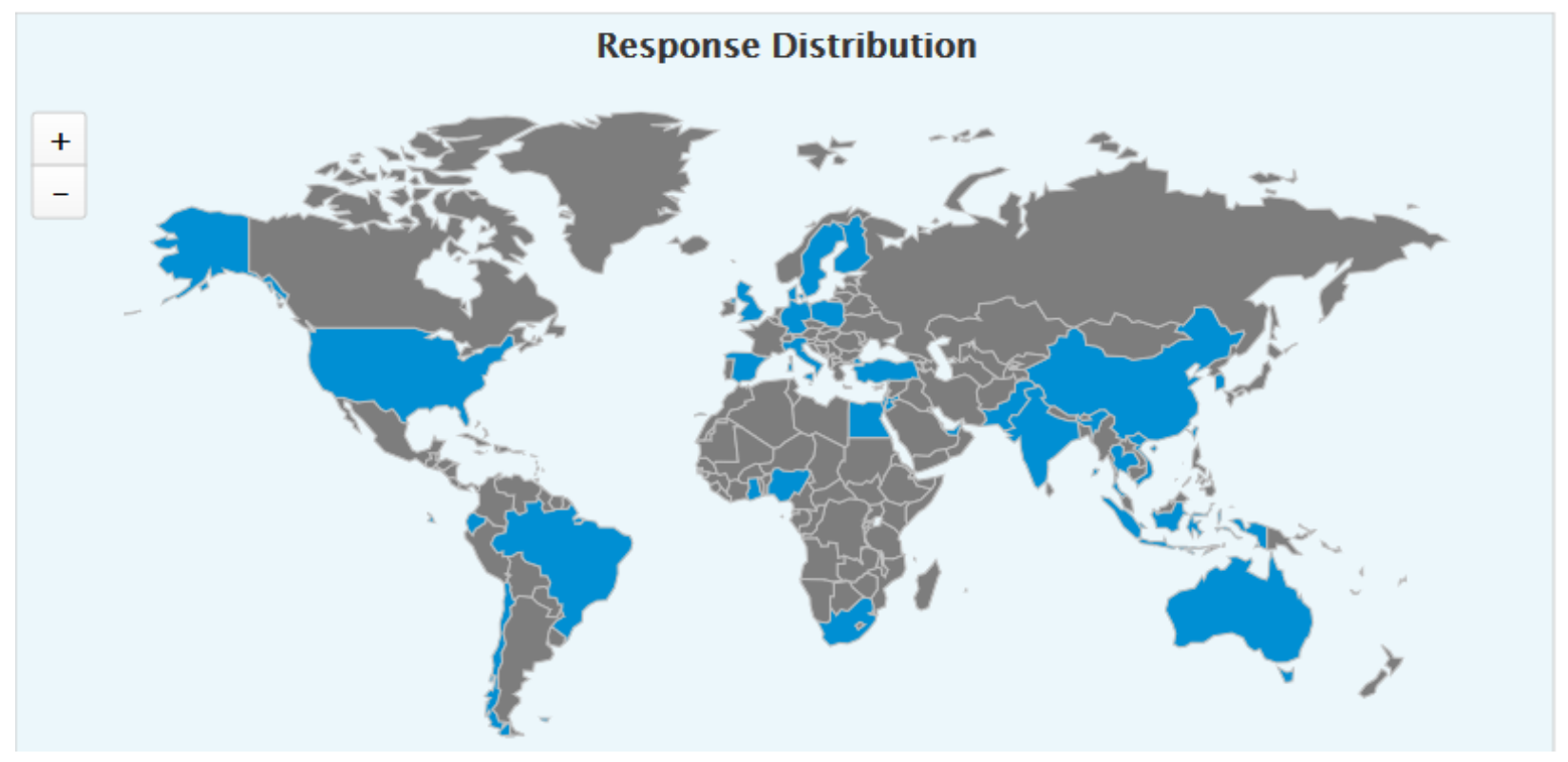

\subsection{Data analysis methods}

The IBM Statistical Package for the Social Sciences (SPSS) version 21 was used to analyse the collected data in this study. First, the reliability and validity of the used data collection tool were examined. Cronbach alpha values and corrected item-total correlation coefficients were used to examine the consistency and reliability of each of the four used constructs. Also, an exploratory factor analysis was used for each of the used items within the four used constructs to examine their construct validity. Second, descriptive analyses were conducted to calculate frequency means for each item within the four constructs that used the five-point Likert level of agreement scale. The standard deviation was also calculated for each item.

\subsection{Reliability and validity of research instrument}

Reliability is defined as an indicator for measuring the homogeneity of the scale items in the same construct (DeVellis, 1991; Hinkin, 1995) and it reflects how well the observed scores are related to the true scores (Lo and Yeung, 2006). Cronbach alpha values and corrected item-total correlation coefficients were used to examine the consistency and reliability of the four used constructs. As shown in Table 5, the Cronbach alpha coefficient value for the benefits to individual organizations construct was 0.935 , for the benefits to entire supply chain construct it was 0.940 , challenges to individual organizations had a coefficient value of 0.906 , and challenges to the entire supply chain construct had a Cronbach alpha coefficient value of 0.947. Rivard and Huff (1988) suggest that Cronbach's values exceeding alpha coefficient of 0.7 thresholds provide reliability evidence for internal consistency of the measurement scales. Although an acceptable reliable coefficient is normally 0.7 or higher, lower thresholds are sometimes used in the literature (Santos, 1999). For new instruments, constructs with reliability values as low as 0.5 is also acceptable (O'Leary-Kelly and Vokurka, 1998). Although the used instrument in this study was new, the Cronbach alpha coefficient values for the four used constructs were all above 0.90. Because the closer to 1 the result is, the more reliable the construct becomes (Cohenet et al., 2003), it can be concluded that this new survey instrument be considered as an extremely reliable research tool. 
Tavakol and Dennick (2011, p.1) explained that "a low value of alpha could be due to a low number of questions, poor inter-relatedness between items or heterogeneous constructs". In our used four survey constructs, we believe the number of examined items under each construct are adequate and provide a thorough picture of the four examined themes. Also, each of the used items, within each construct, is directly related to the main theme of the construct and all of the used statements are inter-related. Thus, we relate the high Cronbach alpha coefficient values of the four used constructs to these two main factors.

The corrected item-total correlation values were also calculated for all the items within the four used constructs. For the first used construct as seen in Table 6, the item-total correlation values ranged from 0.528 to 0.732 . In Table 7 , the second used constructs, these correlation values ranged from 0.469 to 0.772. Table 8 shows that the item-total correlation values for this construct were between 0.520 and 0.741. Finally, the same correlation values for the fourth used construct, as shown in Table 9, ranged between 0.634 and 0.800 . The literature suggests that these item-total correlation values should be at least 0.40 (J. Gliem \& R. Gliem, 2003). Thus, the corrected item-total correlations for all of the included items within the four used structures were all above 0.40 which is encouraging, indicating good internal consistency for the used scale items, and that all the items relate to each other.

Table 5 also shows the participants' agreement levels with each of the four used main constructs. The benefits of individual organizations construct had the highest agreement level with a mean value of 4.11. Followed by the challenges to individual organizations construct (mean $=3.94$ ), the benefits to entire supply chain construct had a mean value of 3.92, and the fourth construct of the challenges to entire supply chain had the least agreement levels with a mean value of 3.88 .

Table 5 Summary of findings in Cronbach alpha reliability test analysis

\begin{tabular}{llllll}
\hline Construct & $\begin{array}{l}\text { No. of } \\
\text { items }\end{array}$ & Mean & SD range & $\begin{array}{l}\text { Cronbach } \\
\text { Alpha }\end{array}$ & $\begin{array}{l}\text { Range of corrected } \\
\text { item-total correlation }\end{array}$ \\
\hline - Benefits to individual organizations & 17 & 4.11 & $0.708-0.834$ & 0.935 & $0.528-0.732$ \\
- Benefits to entire supply chain & 18 & 3.92 & $0.671-0.990$ & 0.940 & $0.469-0.772$ \\
- Challenges to individual organizations & 15 & 3.94 & $0.733-1.039$ & 0.906 & $0.520-0.723$ \\
- Challenges to entire supply chain & 15 & 3.88 & $0.784-0.998$ & 0.947 & $0.634-0.800$ \\
\hline
\end{tabular}

Given the fact that used survey instrument was developed for this study and it has not been used before, an exploratory factor analysis (Principal Component) was used to examine its construct validity. This analysis will help to determine how, and to what extent, each item within the four main used constructs is linked to their underlined factors (Chong et al., 2009). Hair et al., (2006) state that the rule-of-thumb is that factor analysis values greater than 0.30 should be considered significant, values greater than 0.40 should be considered more important, and values that are 0.50 or greater should be considered very significant. As shown in Table 6, the benefits to individual organizations construct had factor loading values ranging from 0.495 to 0.788 . As shown in Table 7 , the benefits to entire supply chain construct generated factor loading values between 0.549 and 0.765. As shown in Table 8, the challenges to individual organizations items factor loading values ranged between 0.431 and 0.812 . Finally, as shown in Table 9, the challenges to entire supply chains construct had values between 0.462 and 0.694 . In summary, out of a total 65 used items in the four constructs; only 3 items had factor loading values below 
0.50 but they were greater than 0.40 and the remaining 62 items had factor loading values greater than 0.50. Also, it is important to note that when the entire survey instrument is run at the SPSS at once (65 items) for factor analysis, the loading values ranged from 0.644 to 0.847 ; thus, the construct validity of the used instrument in this study is very significant.

\section{Analysis and results}

\subsection{Benefits to individual organizations}

The used construct to examine potential benefits of IoT adoption to individual organizations consists of 17 items (see Table 6). The participants were asked to rate these 17 items using a five-point Likert scale ranging from " $1=$ strongly disagree" to " $5=$ strongly agree". The 17 items were; more transparency and visibility of information and material flows, improved integration of internal business processes, better proactive replenishment of material, better predictive maintenance of assets, improved in company assets utilization, reduction in machinery loss and downtimes, better facilitation of product development and commercialization, developed operational proficiency, improved fleet and transportation management, better control and management of inventories, improved product tracking and traceability, better production process optimization by detecting conflicts and inefficiencies, cost saving during production process in raw material, energy, water, manpower, machine, equipment, prediction of optimal level of production by reducing overproduction and underproduction, better support to e-commerce platforms through reliability and availability in information, improved production adjustments based on real-time information of the demand and capacity availability, capturing better insights about customer patterns and behaviour, and procurement strategies optimization in product recovery operations, i.e. acquisition mgmt. for end-of-use products.

Results, as shown in Table 6, indicate that the top five potential benefits an individual organization is likely to gain from the adoption of IoT as perceived by the participants were: more transparency and visibility of information and material flows (mean $=4.39$ ). This result supports the theoretical benefits pointed on several studies regarding the importance of accuracy and availability of real time information and the operations transactions along forward and reverse movement of physical goods in both services and manufacturing industry (Sun, 2012; Ting et al., 2010; Xu et al., 2012; Reaidy et al., 2014; Kumar et al., 2016). The second top ranked benefit was the improvement in products tracking and traceability $($ mean $=4.34)$, a crucial element within services and manufacturing operations to achieve efficiency enhancements in productivity through synchronized flow of material and information (Costa et al., 2012; Cao et al., 2013; Uddin and Sharif, 2016). Better control and management of inventories benefit took the third position (mean $=4.29$ ), which supports theoretical and empirical evidences of studies in this field to develop operational performance in replenishment processes and warehousing management through reduction of inefficiencies of inaccuracy in inventory data (Fan et al., 2015; Reaidy et al., 2015; Thiesse and Buckel, 2015). The fourth perceived potential benefit was the improved integration of internal business processes $($ mean $=4.18)$. Besides the optimization of internal production process (Mann, 2015), the use of IoT provides a competitive advantage to a business and enables a strategic redesign of all operations business processes in integrated fashion to enable operational performance improvements (Ferreti and Schiavone, 2016). The fifth benefit was identified as a developed operational efficiency (mean $=4.17$ ). This is a potential benefit that will allow enterprises to actively participate in relevant business opportunities along several business dimensions such as; distributions, procurement and in 
production by shortening the distances between entities, optimizing inventory levels, and reducing costs based on effective and dynamic operational strategies (Li and Li, 2017).

Conversely, the five least potential benefits were: Facilitate product development and commercialization $($ mean $=3.86)$. Companies continue to develop products based on hardware improvements, away from customer involvement, and in a fragmented way. The IoT concept, on the other hand, focuses on the service design in an integrated model where customer involvement is a key to the creation of a new dimension of products and services. Such approach is managed through a virtual model wherein new products with sensors demand continuous improvements based on real time data collection (Westerbeek, 2016; Turunen, 2017). The success of adopting IoT to develop product commercialization still largely depends on the industry to address residual challenges related to standardization and commercialization of sensors and microelectromechanical systems (Grace et al., 2015). Procurement strategies optimization in product recovery operations, i.e. acquisition management for end-of-use products was perceived as the second lowest potential benefit (mean $=3.91$ ). Although product recovery is a relevant topic under research in production management field (Fan et al., 2016), this result supports the current state of the use of smart objects information in product lifecycle management where the use of IoT with product data technologies and STEP, the ISO 10303 standard to describe product information throughout its lifecycle, still lacks exploration (Kiritsis, 2011). Cost saving during production process in raw material, energy, water, human, machine, equipment was perceived as the third least potential benefit (mean = 3.92). Several industries have already achieved some cost-reduction benefits as a result of adopting IoT but such adoption is not embraced by enterprises in a large scale (Kerravala, 2017; Schimek, 2017; Tracy, 2017). Intel and Fujitsu (Intel, 2017) revealed that operational efficiencies and cost savings in manufacturing processes as two key benefits from the IoT adoption. Furthermore, the prediction of optimal level of production by reducing overproduction and underproduction (mean $=3.94$ ) was perceived as the fourth least expected potential benefit. Several leaders from discrete manufacturing industry e.g. Siemens, General Electric, Cisco and Harley-Davidson gained benefits from implementing smart production with intelligent and automated decisions in their manufacturing plants through the use of IoT. This has enabled them to; improve profitability, identify improvement opportunities, and effectively resolve business problems (O'Marah, 2015). On the other hand, production process optimization by detecting conflicts and inefficiencies was perceived as the lowest potential benefit (mean = 3.95). As advocated by Zhou et al. (2017) and demonstrated by Kang et al., (2016), IoT technologies facilitates the global optimization of conventional production process in manufacturing environments, e.g. production, transportation, storage, equipment, information, services and decision-making processes, through dynamic synchronization of multi-stage production system. Ghashghaee (2016) stated that Volvo car manufacturer adopted the IoT technology in one of its large automotive assembly plants and the key benefits from such implementation was the 'production process optimization'. Although this perceived potential benefit was rated relatively low, the significance level of this benefit was strongly defended by researchers, specialists, and practitioners.

In summary, the low rated potential benefits IoT may provide to an organization are supported by several factors and challenges confirmed by the IoT Institute. This includes: operations lacking defined workflows, doubts about obtaining the expected benefits, interconnection difficulties with existing legacy ICT systems, high costs of infrastructure installation and related services, lack of required knowledge and skills, and concerns with data sharing and security (Buntz, 2016). 
Table 6 Participants' perception of loT potential benefits to individual organizations

\begin{tabular}{|c|c|c|c|c|}
\hline Items & Mean & $\begin{array}{l}\text { Item-Total } \\
\text { Correlation }\end{array}$ & $\begin{array}{l}\text { Factor } \\
\text { loading }\end{array}$ & Rank \\
\hline $\begin{array}{l}\text { - More transparency and visibility of information and } \\
\text { material flows }\end{array}$ & 4.39 & 0.528 & 0.576 & 1 \\
\hline - Improved products tracking and traceability & 4.34 & 0.611 & 0.581 & 2 \\
\hline - Better control and management of inventories & 4.29 & 0.710 & 0.680 & 3 \\
\hline - Improved integration of internal business processes & 4.18 & 0.683 & 0.764 & 4 \\
\hline - Development of operational efficiency & 4.17 & 0.662 & 0.788 & 5 \\
\hline $\begin{array}{l}\text { - Better support to e-commerce platforms through } \\
\text { reliability and availability in information }\end{array}$ & 4.17 & 0.537 & 0.495 & 6 \\
\hline - Improved fleet and transportation management & 4.16 & 0.732 & 0.610 & 7 \\
\hline - Better predictive maintenance of assets & 4.15 & 0.637 & 0.641 & 8 \\
\hline $\begin{array}{l}\text { - Production adjustments based on real-time information } \\
\text { of the demand and capacity availability }\end{array}$ & 4.15 & 0.638 & 0.766 & 9 \\
\hline - Insights from customer patterns and behaviour & 4.14 & 0.688 & 0.643 & 10 \\
\hline - Better proactive replenishment of material & 4.09 & 0.694 & 0.602 & 11 \\
\hline $\begin{array}{l}\text { - Improvement in company assets utilization, reduction in } \\
\text { machinery loss and downtimes }\end{array}$ & 4.05 & 0.687 & 0.622 & 12 \\
\hline $\begin{array}{l}\text { Production process optimization by detecting conflicts } \\
\text { and inefficiencies }\end{array}$ & 3.95 & 0.689 & 0.612 & 13 \\
\hline $\begin{array}{l}\text { Prediction of optimal level of production by reducing } \\
\text { overproduction and underproduction }\end{array}$ & 3.94 & 0.649 & 0.691 & 14 \\
\hline $\begin{array}{l}\text { - Cost saving during production process in raw material, } \\
\text { energy, water, human, machine, equipment. }\end{array}$ & 3.92 & 0.719 & 0.629 & 15 \\
\hline $\begin{array}{l}\text { - Procurement strategies optimization in product recovery } \\
\text { operations, i.e. acquisition mgmt. for end-of-use products }\end{array}$ & 3.91 & 0.589 & 0.572 & 16 \\
\hline - Facilitate product development and commercialization & 3.86 & 0.695 & 0.549 & 17 \\
\hline
\end{tabular}

\subsection{Benefits to entire supply chains}

The used construct to examine potential benefits of IoT adoption to entire supply chains consists of 18 items including; reshaping models of SCM considering autonomous parts from a digitalized value chain with electronic network of activities, better integration along inter-organisational business processes, development of real time SCM with reduction of data distortion and improvement of business intelligence, reduction of transactional inter-enterprises reactions, reduction of inventory levels throughout SC nodes, reduction of Bullwhip effect within SCs, more transparency from local and international logistics operations, improved management resolution by involving additional elements within SC operational processes, decentralization of decisions - computing power and processing time can be redirected to critical areas along the SC network based on availability and reliability of real-time data, emerging of innovative operational architectures with analytical approaches and collaborative winwin model, improved control and management of SC footprint to ensure regulation compliance, execution of simulations, optimizations and data analytics processes to improve SC OP effectiveness, supply Chains will start to act in a predictable manner instead of reacting to the market needs, enhancing the real-time visibility of demand and capacity fluctuations, improving Just-in-Time manufacturing through better production scheduling, development of reliability, responsiveness and agility through fast exchange of 
real-time information and facilitating process activities improvements, developing the performance management of SCs by reducing delays in data colleting and assessing and acting, and better optimization of joint procurement process to the acquisition of used products in remanufacturing operations.

Results, as shown in Table 7, indicate that the top five potential benefits entire supply chains are likely to obtain from the adoption of IoT, as perceived by the participants, were: development of real time SCM with reduction of data distortion and improvement of business intelligence has shown to exert the strongest potential benefit from IoT adoption (mean $=4.15)$. We were able to confirm the importance of this benefit in line with previous works (e.g. Atzori et al., 2010; Uckelmann et al., 2011; Xu, 2011; Bi et al., 2014; Bughin et al., 2015; Dweekat et al., 2017). Second, SCs performance management improvement by reducing delays in data collection, assessment, and decision-making was perceived as the second strongest potential benefit SCs would gain from adopting IoT (mean $=4.07$ ). This finding matches what other studies have emphasized as the crucial role IoT plays in enhancing performance of SCs; however, there were no ratings for this potential benefit in these studies (e.g. Biswas and Sen, 2016; Dweekat and Park, 2016; Dweekat et al., 2017). A third potential benefit that proved important is the better integration of inter-organisational business processes (mean $=4.06$ ). However, our study concluded this potential benefit in the third place but other studies (e.g. Da Xu et al., 2014; Macaulay et al., 2015; Ferretti and Schiavone, 2016) highlighted this benefit as more significant. This is perhaps due to the fact that the adoption of IoT has moved to a more advanced stage where enterprises are seeking to achieve more strategic oriented benefits e.g. enhancing the overall SCs operational performance in alignment with new business strategic models wherein decision are taken based on reliable and real time data to the creation of innovative portfolio of products and services (Wagenaar, 2012; Gerpott and May, 2016; Zhong et al., 2016) (e.g. He and $\mathrm{Da} \mathrm{Xu,} \mathrm{2014;} \mathrm{Chan} \mathrm{et} \mathrm{al.,} \mathrm{2016;} \mathrm{Lee,} \mathrm{2016;} \mathrm{Li} \mathrm{and} \mathrm{Li,} \mathrm{2017)} \mathrm{and} \mathrm{as} \mathrm{it} \mathrm{has} \mathrm{been}$ highlighted as the first and second top potentials benefits in this study. A fourth potential benefit that was ranked as significant was the transparency from local and international logistics operations (mean = 4.06). We were able to confirm the significance of this potential benefit and this goes in line with prior research works (e.g. Lee and Lee, 2015; Reaidy et al, 2015; Wieland et al., 2016). The fifth most perceived potential benefit SCs would gain from adopting IoT was the development of reliability, responsiveness and agility through fast exchange of real-time information and facilitating process activities improvements (mean $=4.05)$. The confirmation of the significance of these benefits goes in line with those highlighted in previous research works (e.g. Bi et al., 2014; Reaidy et al, 2015; Dweekat et al., 2017).

Conversely, while some of the examined benefits were ranked high, other potential theoretical benefits could not be strongly supported and the impact of IoT adoption on these changes was perceived less significant. The first least perceived benefits was that supply chains will start to act in a predictable manner instead of reacting to the market needs (mean $=3.63$ ). This finding seems to contradict with outcomes of other research works (e.g. Tao et al., 2014; Lee and Lee, 2015; Pang et al., 2015; Michaelides, 2016) where predictions of e.g. demand, risk, shelf-life, future outcomes, etc. have been seen as significant benefits IoT adoption can bring to SCM. The second least perceived potential benefit was the reduction of transactional inter-enterprises reactions (mean $=3.76$ ). The influence of IoT adoption on reduction of transactional inter-enterprises reactions could not be strongly supported. Perhaps this was because it was unclear how such an impact may occur in practice or due to the still existing major barrier on having all SC entities actively participating as network nodes of an IoT ecosystem that interoperate through a homogeneous architecture of information model (Bröring et al., 2017). The third 
least supported potential benefit was the improvement of management resolution by involving additional elements within SC operational processes $($ mean $=3.77)$. While prior studies explained that IoT adoptions support decision-making processes (e.g. Bi et al., 2014; Da Xu et al., 2014; Reaidy et al, 2015) this study suggests that IoT adoption does not significantly impact management resolution processes. Perhaps IoT adoption is still immature due the significant costs related to technological and geographical coverage limitations in extending the sensing environment infrastructure throughout the whole supply chain. Thus, this prevents top management from utilizing the full potentials of increased operations visibility promoted by higher-resolution of data gathered from dynamic mapping of physical and virtual space to achieve business excellence (Fleish, 2010; Vermesan et al., 2011; Fleisch et al., 2014). The fourth least perceived potential benefit was the optimization of joint procurement process to the acquisition of used products in remanufacturing operations $($ mean $=3.85)$. Although prior works (e.g. Ondemir and Gupta, 2014; Fang et al., 2016) strongly suggested the IoT adoption significantly optimizes procurement, production and product recovery, and acquisition; recent research reveals that enterprises and procurement practitioners across Europe, UK and North America are still not strategically adopting IoT as a catalyst for deployment of innovative procurement solutions (Avery, 2015). The fifth least supported potential benefit was IoT as a disruptive technology that will reshape models of SCM considering autonomous parts from a digitalized value chain with electronic network of activities (mean = 3.85). Mixed responses have been collected about this potential benefit. A conceivable explanation about this may be found in the fact that IoT is seen by some as a revolution that will reshape entire supply chains but it is seen by others as an enabling technology that will contribute to the digitization of SCs in addition to other enabling technologies that will together and gradually reshape existing models of SCM (Lightwell, 2014). Therefore, revealing the difficulty of stablishing an effective model of governance to a structured ecosystem and the logic regarding how the value will be created, delivered and captured to all supply chains stakeholders (Fleish et al., 2014; Chan, 2015).

Table 7 Participants' perception of IoT potential benefits to entire supply chain

\begin{tabular}{|c|c|c|c|c|}
\hline Items & Mean & $\begin{array}{l}\text { Item-Total } \\
\text { Correlation }\end{array}$ & $\begin{array}{l}\text { Factor } \\
\text { loading }\end{array}$ & Rank \\
\hline $\begin{array}{l}\text { Development of real time SCM with reduction of data } \\
\text { distortion and improvement of business intelligence }\end{array}$ & 4.15 & 0.533 & 0.600 & 1 \\
\hline $\begin{array}{l}\text { - Develop the performance management of SCs by reducing } \\
\text { delays in data colleting and assessing and acting. }\end{array}$ & 4.07 & 0.654 & 0.647 & 2 \\
\hline $\begin{array}{l}\text { - Better integration along inter-organisational business } \\
\text { processes }\end{array}$ & 4.06 & 0.685 & 0.625 & 3 \\
\hline $\begin{array}{l}\text { - Transparency from local and international logistics } \\
\text { operations }\end{array}$ & 4.06 & 0.704 & 0.693 & 4 \\
\hline $\begin{array}{l}\text { Development of reliability, responsiveness and agility } \\
\text { through fast exchange of real-time information and } \\
\text { facilitating process activities improvements }\end{array}$ & 4.05 & 0.688 & 0.662 & 5 \\
\hline $\begin{array}{l}\text { - Enhancement the real-time visibility of demand and capacity } \\
\text { fluctuations }\end{array}$ & 4.01 & 0.647 & 0.679 & 6 \\
\hline $\begin{array}{l}\text { Improvement in Just-in-Time manufacturing through better } \\
\text { production scheduling }\end{array}$ & 4.01 & 0.662 & 0.580 & 7 \\
\hline $\begin{array}{l}\text { - Improvement in the control and management of SC foot } \\
\text { print to ensure regulation compliance. }\end{array}$ & 3.97 & 0.660 & 0.549 & 8 \\
\hline - Reduction of Bullwhip effect within SCs & 3.95 & 0.469 & 0.765 & 9 \\
\hline
\end{tabular}


- Execution of simulations, optimizations and data analytics processes to improve SC OP effectiveness

$\begin{array}{llll}3.94 & 0.602 & 0.731 & 10\end{array}$

- Reduction of inventory levels throughout $\mathrm{SC}$ nodes

3.87

0.701

0.557

11

- A disruptive technology that will reshape models of SCM considering autonomous parts from a digitalized value chain

0.733

0.608

12 with electronic network of activities

- Optimization of joint procurement process to the acquisition of used products in remanufacturing operations

- Emerging of innovative operational architectures with analytical approaches and collaborative win-win model

- Decentralization of decisions - computing power and processing time can be redirected to critical areas along the SC network based on availability and reliability of real-time data.

- Improve management resolution by involving additional elements within SC operational processes

$\begin{array}{llll}3.77 & 0.764 & 0.681 & 16 \\ 3.76 & 0.772 & 0.687 & 17 \\ 3.63 & 0.760 & 0.677 & 18\end{array}$

- Reduction of transactional inter-enterprises reactions

- Supply Chains will start to act in a predictable manner instead of reacting to the market needs

\subsection{Challenges to individual organizations}

The used construct to examined potential challenges an organization may face when implementing IoT has 15 items (Table 8) as follows: no clear comprehension about the IoT benefits, risks associated with implementation of new business model(s), technical and technological integration challenges, device and network security risks and vulnerabilities, applications coding development challenges, enterprise management, data management, and operational processes integration difficulties, the need for seamless integration of business processes, information and communication technologies in cyberspace, employees' resistance to new technologies and practices, displacement of human resources, challenges with obtaining the needed supporting staff with right skills and knowledge, malicious and unintentional security incidents involving employees, contractors and vendors, loss of privacy, trust, confidentiality and availability risks, availability of financial resources to implement and maintain IoT, compatibility among sensors, networks and applications from different technology and vendors, and integration with technologies and operations outside operational boundaries.

Results, as shown in Table 8, indicate the top five potential challenges an individual organization is likely to face when adopting IoT, as perceived by the participants, were: lack of a clear comprehension about the IoT benefits $($ mean $=4.18)$ was perceived as the top challenge to IoT adoption. Although hundreds of papers have been published covering technological and technical challenges related to IoT technologies, the multi-applications and multi-technologies from IoT are still in the early development stages (Ryan and Watson, 2017). Therefore, a clear understanding regarding the long capital cycle and holistic comprehension of full potential business benefits achieved from the use of IoT are still major challenges to most of enterprises and practitioners (Da Xu et al., 2014; Lee and Lee, 2015; Ryan and Watson, 2017). In the second place, challenges with obtaining the needed supporting staff with the right skill sets and knowledge (mean $=4.16)$ was seen as another key challenge. Ryan and Watson (2017) highlight that effectiveness in designing and deploying IoT solutions requires a set of knowledge across several technical and non-technical disciplines. This was also supported by other researchers (e.g. Hung, 2016; 
Petel et al., 2017). Risks associated with implementation of new business model (mean $=4.06$ ) was rated as the third top potential challenge. The incentive of adopting IoT is linked with potential financial returns through the generation of new economic opportunities. Enterprises must clearly understand how value will be created, delivered and captured considering financial return as a key in IoT. Also, they should evaluate the differences between business models from others applications and IoT application where combination of services and products are delivered through smart products within dynamic, wider and complex environments (Dijkman et al., 2015; Hognelid and Kalling, 2015; Pfisterer et al., 2016). Furthermore, the technical and technological integration challenges (mean $=4.05$ ) was seen and the fourth top challenge to the IoT implementation. The difficulties with establishing interoperability and seamless integration between different technologies and network systems to create cyber-physical infrastructure of IoT ecosystems are seen by several researchers as key barriers associated with the adoption of IoT solutions (Da Xu et al., 2014; Buntz, 2015; Hussain, 2016; Valmohammadi, 2016). Finally, the fifth perceived top potential challenge was the integration with technologies and operations outside operational boundaries (mean $=4.01$ ). Although IoT applications and solutions are recognized as very important across industries, the challenges related with internal and external integration of vertical, heterogeneous and closed systems remain major concerns to enterprises (Gnimpieba et al., 2015; Valmohammadi, 2016; Hussain, 2016; Bröring et al., 2017).

On the other hand, the least five perceived potential challenges were: displacement of human resources (mean $=3.54$ ). Although this potential challenge was ranked low; several economic researches advocates that the adoption of IoT will create relevant challenges at social and organisational levels regarding rearrangement of skilled and unnecessary manpower (O'Halloran and Kvochko, 2015; Cottong, 2016; Ryan and Watson, 2017). Thus, it is important to explore ways to involve the existent human resources instead of displace or replace them (Iansiti and Lakhani, 2014). The applications coding development (mean $=3.66$ ) was perceived as the second perceived least challenge. According to several recent studies, a challenge that many organisations will need to face when adopting IoT solutions will be the talent shift of the required professional skills from software programmers to content analysis and value creation through data analytics for optimization and prediction applications (Petel et al., 2017; Rymaszewska et al., 2017). The third perceived least challenge was the availability of financial resources to implement and maintain (mean $=3.79$ ). The implementation of IoT solutions requires sensors and physical layer connectivity elements. It also requires; data storage, data processing, data mining, and data security. In addition, it requires skilled professionals to develop, and continuous support, different necessary applications. On the other hand, the investment in innovative technologies such as IoT always carries a significant risk of financial loss and irreversibility of investments to organisations (Ericsson, 2015; Lee and Lee, 2015). Therefore, the limited number of IoT adoption case studies showing clear return-oninvestment gains across industries creates a considerable barrier for single enterprises to embraces such disruptive innovative technology. The fourth least perceived challenge was the avoidance of malicious and unintentional security incidents involving employees, contractors and vendors (mean $=3.80)$. Security risks related with; verification, authorization, privacy, access to the system, applications, network, and data remain one of the main challenges for organisations when managing IoT ecosystems (Alaba et al., 2017). Thus, the human element is still considered as a constant risk of security incidents due the lack of managerial and maintenance care about access control within enterprises' ICT networks (Patel et al., 2017). Therefore, the low ranking of this challenge doesn't reflect a comprehensive reality of current research trends in IoT security issues for organisations. Finally, the compatibility among sensors, 
networks and applications from different technology and vendors (mean $=3.84$ ) as the fifth least challenge and organization may face when adopting IoT. The interoperability among non-standard protocols and sensors is a real challenge for inter companies integration. Different technologies along distributed and heterogeneous organisational IoT environments must be seamlessly integrated. Also, the design and development of IoT solutions within enterprise boundaries, i.e. in an isolated ecosystem, allows the achievement of a much better degree of compatibility, integration and interoperability among smart objects, wireless sensor network, communication protocol, cloud computing, and applications (Da Xu et al, 2014; Ghashghaee, 2016; Hussain, 2016; Alaba et al., 2017).

Although not recognized at individual enterprises level, the displacement of human resources will be a key consequence that many organisation will face when embracing disruptive technologies such as IoT that will merge embedded system technology with smart industrial production process. Also, the level of data security, integrity and avoidance of intentional behaviour to the access of confidential information are certainly major concerns within certain sectors such as governmental and military; however, these were not perceived as very significant challenge by the participants in this study.

Table 8 Participants' perception of loT potential challenges to individual organizations

\begin{tabular}{|c|c|c|c|c|}
\hline Items & Mean & $\begin{array}{l}\text { Item-Total } \\
\text { Correlation }\end{array}$ & $\begin{array}{l}\text { Factor } \\
\text { loading }\end{array}$ & Rank \\
\hline - Device and network security risks and vulnerabilities & 4.23 & 0.583 & 0.542 & 1 \\
\hline - Lack of a clear comprehension about the loT benefits & 4.18 & 0.616 & 0.670 & 2 \\
\hline $\begin{array}{l}\text { - Challenges in obtaining the needed supporting staff with } \\
\text { right skills and knowledge }\end{array}$ & 4.16 & 0.723 & 0.745 & 3 \\
\hline $\begin{array}{l}\text { - Risks associated with implementation of new business } \\
\text { model }\end{array}$ & 4.06 & 0.592 & 0.431 & 4 \\
\hline - Technical and technological integration & 4.05 & 0.533 & 0.571 & 5 \\
\hline $\begin{array}{l}\text { - Integration with technologies and operations outside } \\
\text { operational boundaries }\end{array}$ & 4.01 & 0.741 & 0.759 & 6 \\
\hline $\begin{array}{l}\text { - Enterprise management, data management, and } \\
\text { operational processes integration }\end{array}$ & 4.00 & 0.627 & 0.515 & 7 \\
\hline - Loss of privacy, trust, confidentiality and availability risks & 3.97 & 0.646 & 0.686 & 8 \\
\hline - Employees' resistance to new technologies and practices & 3.94 & 0.520 & 0.597 & 9 \\
\hline $\begin{array}{l}\text { - Seamless integration of business processes, information } \\
\text { and communication technologies in cyberspace }\end{array}$ & 3.87 & 0.564 & 0.513 & 10 \\
\hline $\begin{array}{l}\text { - Compatibility among sensors, networks and applications } \\
\text { from different technology and vendors }\end{array}$ & 3.84 & 0.538 & 0.628 & 11 \\
\hline $\begin{array}{l}\text { - Avoidance of malicious and unintentional security } \\
\text { incidents involving employees, contractors and vendors }\end{array}$ & 3.80 & 0.595 & 0.719 & 12 \\
\hline $\begin{array}{l}\text { - Availability of financial resources to support } \\
\text { implementation and maintenance }\end{array}$ & 3.79 & 0.549 & 0.627 & 13 \\
\hline - Applications coding development & 3.66 & 0.531 & 0.812 & 14 \\
\hline - Displacement of human resources & 3.54 & 0.615 & 0.747 & 15 \\
\hline
\end{tabular}

\subsection{Challenges to entire supply chains}

This construct was used to examine potential risks and challenges the entire supply chain would face when the IoT is adopted across the network and these include 15 potential challenges; global standard of 
IoT communication protocol for smart objects and systems, integration along multiples supply chains with heterogeneous technologies and data services, services platforms of storage to accommodate large volume of data with high levels of security and reliability, financial investments from all participants to design and deploy IoT technologies and solutions, the design of new SC business models to support the still unstructured firm-oriented ecosystems, solutions for communication and signal coverage to attend different modes of transport and products, services and technological products still not mature, identification of the economic model that will define and capture the business value for the benefit of SCM, effective layers of security to eliminate sources of vulnerabilities throughout the SC nodes and links, common managerial comprehension about IoT along SC main stakeholders, establishment of effective IoT architecture throughout SCs involving objects, network, data services, and applications layers, diversity of industries operational models from common SC participants, challenge in Just in Time manufacturing regarding dynamic production scheduling, effective integration and synchronization of data and cloud computing systems, and platforms to manage and control huge volume of data, velocity of processing, validation and diversity of information.

Results, as shown in Table 9, indicate that the top five potential challenges entire supply chains are likely to face when IoT is adopted, as perceived by participants, were: integration along multiples Supply Chains with heterogeneous technologies and data services (mean $=4.10)$. We confirmed that integrating IoT technologies with existent used operational, analytics and strategic systems/technologies within SCs is the most perceived challenge to adopting IoT successfully. This challenge was identified as one of the top difficulties by other researchers, too (e.g. Bi et al., 2014; Bughin et al., 2015; Riggins and Wamba; 2015). The second perceived top IoT adoption challenge was developing global standard of IoT communication protocol for smart objects and systems (mean $=4.01)$. This is a common challenge with new technologies adoption and this confirms similar concerns highlighted in some prior works (e.g. Fang et al., 2014; Tao et al., 2014; Riggins and Wamba; 2015; Tan and Koo, 2014). The third supported key challenge to IoT adoption is creating effective layers of security to eliminate sources of vulnerabilities throughout the $S C$ nodes and links (mean = 3.98). This risk remains an issue that needs to be addressed when IoT is adopted. IoT devices are likely to be vulnerable to security risks due to lack of transport encryption, insecure Web interfaces, inadequate software protection, and insufficient authorization. Although we were able to confirm that such risks are still important for IoT adoption, this potential challenge came third. Prior research works have considered security variability as the key challenge among other challenges (e.g. Lee and Lee, 2015; Reaidy et al., 2015; Riggins and Wamba, 20195; Martellini et al., 2017). The fourth perceived challenge associated with IoT adoption was common managerial comprehension about IoT along SC main stakeholders (mean $=3.97$ ). Although this theoretical challenge remains legitimate to several scholars, its degree of authenticity should be explored and validated along professionals of the SCM discipline and OEMs. It seems that knowledge about IoT is still limited to professionals and academics in general. For example, 115 participants viewed the used survey in our study but did not start completing it. Also, 124 started completing the survey but dropped before fully completing it. One possible reason behind this could be the lack of knowledge participants have about the survey topic. The fifth top supported potential challenge to IoT adoption was the establishment of effective IoT architecture throughout SCs involving objects, network, data services, and applications layers (mean $=3.93$ ). We confirmed that such a challenge remains significant for a successful IoT adoption. This goes in line with several prior works that discussed similar challenges (e.g. Bi et al., 2014; Jin et al., 2014; Bughin et al., 2015; Li et al., 2015). 
While the four least perceived potential challenges were: first, challenge with Just-in-Time manufacturing regarding dynamic production scheduling (mean $=3.67$ ). We could not confirm that this challenge is significant to IoT adoption. A conceivable justification for this may be found in the fact that IoT has already been widely used for planning and scheduling purposes and such a challenge will diminish as organizations adopt the IoT more. Such benefit was presented on some prior publications (e.g. Bi et al., 2014; Reaidy et al., 2015; Yan and Yan, 2017). The second least challenge to IoT adoption was solutions for communication and signal coverage to attend different modes of transport and products (mean $=$ 3.77). This challenge was not seen as a major issue to IoT adoption. This could be attributed to technological advancements in certain applications that continue to introduce better solutions at more affordable prices which will lead to wider IoT implementations (Bughin et al., 2015; Riggins and Wamba, 2015). However, another reason why some participants still saw this challenge as an issue could mainly be related to lack of signal coverage in certain physical manufacturing premises or on transportation fleet on the roads (Fang et al., 2014; Yan et al., 2014). The third least supported challenge was services and technological products still not mature (mean $=3.80$ ). We confirmed that IoT products and services are no longer in the infancy stage. More and more IoT-related technologies, devices, software, etc. are introduced and organizations are progressively starting adopting more applications. This is an interesting finding that sends a message about expanding of IoT adoption in general. This supports a number of prior works discussions about IoT adoption (e.g. Bughin et al., 2015; Lee and Lee, 2015; Yan and Yan, 2017). The fourth least supported challenge was design of new SC business models to support the still unstructured firm-oriented ecosystems (mean $=3.84$ ). We confirmed that IoT adoption will impact the current traditional SCs business models. This implies that IoT adoption will gradually change the way of doing things which will ultimately lead to designing, and adopting, new business models. However, such a change will require time and transitioning efforts and perhaps that is why this challenge was ranked relatively low. This line of thoughts goes in line with other prior works (e.g. Jin et al., 2014; Tao et al., 2014; Bughin et al., 2015).

Table 9 Participants' perception of loT potential challenges to entire supply chain

\begin{tabular}{|c|c|c|c|c|}
\hline Items & Mean & $\begin{array}{l}\text { Item-Total } \\
\text { Correlation }\end{array}$ & $\begin{array}{l}\text { Factor } \\
\text { loading }\end{array}$ & Rank \\
\hline $\begin{array}{l}\text { Integration along multiples Supply Chains with } \\
\text { heterogeneous technologies and data services }\end{array}$ & 4.10 & 0.634 & 0.462 & 1 \\
\hline $\begin{array}{l}\text { - Global standard of loT communication protocol for smart } \\
\text { objects and systems }\end{array}$ & 4.01 & 0.666 & 0.504 & 2 \\
\hline $\begin{array}{l}\text { - Effective layers of security to eliminate sources of } \\
\text { vulnerabilities throughout the SC nodes and links }\end{array}$ & 3.98 & 0.800 & 0.694 & 3 \\
\hline $\begin{array}{l}\text { - Common managerial comprehension about loT along SC } \\
\text { main stakeholders }\end{array}$ & 3.97 & 0.738 & 0.607 & 4 \\
\hline $\begin{array}{l}\text { - Establishment of effective loT architecture throughout SCs } \\
\text { involving objects, network, data services, and applications } \\
\text { layers }\end{array}$ & 3.93 & 0.710 & 0.564 & 5 \\
\hline $\begin{array}{l}\text { - Services platforms of storage to accommodate large } \\
\text { volume of data with high levels of security and reliability }\end{array}$ & 3.90 & 0.778 & 0.660 & 6 \\
\hline $\begin{array}{l}\text { - Identification of the economic model that will define and } \\
\text { capture the business value for the benefit of SCM }\end{array}$ & 3.89 & 0.682 & 0.526 & 7 \\
\hline $\begin{array}{l}\text { Platforms to manage and control huge volume of data, } \\
\text { velocity of processing, validation and diversity of }\end{array}$ & 3.89 & 0.660 & 0.501 & 8 \\
\hline
\end{tabular}




\begin{tabular}{|c|c|c|c|c|}
\hline Items & Mean & $\begin{array}{l}\text { Item-Total } \\
\text { Correlation }\end{array}$ & $\begin{array}{l}\text { Factor } \\
\text { loading }\end{array}$ & Rank \\
\hline information & & & & \\
\hline $\begin{array}{l}\text { - Financial investments from all participants to design and } \\
\text { deploy loT technologies and solutions }\end{array}$ & 3.86 & 0.712 & 0.569 & 9 \\
\hline $\begin{array}{l}\text { - Diversity of industries operational models from common } \\
\text { SC participants }\end{array}$ & 3.86 & 0.697 & 0.545 & 10 \\
\hline $\begin{array}{l}\text { - Effective integration and synchronization of data and } \\
\text { cloud computing systems }\end{array}$ & 3.86 & 0.775 & 0.659 & 11 \\
\hline $\begin{array}{l}\text { - Design of new SC business models to support the still } \\
\text { unstructured firm-oriented ecosystems }\end{array}$ & 3.84 & 0.699 & 0.551 & 12 \\
\hline - Services and technological products still not mature & 3.80 & 0.669 & 0.507 & 13 \\
\hline $\begin{array}{l}\text { - Solutions for communication and signal coverage to } \\
\text { attend different modes of transport and products }\end{array}$ & 3.77 & 0.776 & 0.662 & 14 \\
\hline $\begin{array}{l}\text { - Challenge with Just-in-Time manufacturing regarding } \\
\text { dynamic production scheduling }\end{array}$ & 3.67 & 0.770 & 0.653 & 15 \\
\hline
\end{tabular}

\section{Conclusions}

\subsection{Conclusions and recommendations}

This study used a reliable and valid research instrument that included 65 scale items. These items were divided into four constructs namely; IoT adoption benefits to individual organizations (17 items), IoT adoption benefits to entire supply chain (18 items), IoT adoption challenges/risks to an individual organization (15 items), and IoT adoption challenges/risks to entire supply chain (15 items). In conclusion, the study demonstrated the following: The mean values for the examined 35 potential benefits, for an organization and its supply chain, were 3.63 and above on a five-point scale and had mode values of 4 and 5. These were equivalent to 'Agree' and 'Strongly Agree' on the used five-point agreement Likert scale. This indicated that IoT can provide valuable benefits and may result in achieving competitive advantages for individual organizations and their entire supply chains. On the other hand, the participants rated high the examined 30 potential challenges an individual organization and its supply chain are likely to face when adoption IoT. The mean values of the examined 30 items had 3.54 and above and mode values of 4 and 5. These were equivalent to 'Agree' and 'Strongly Agree' on the used five-point agreement Likert scale. This indicates that there are still a number of recognized challenges and risks that organizations need to overcome before adopting IoT and harvest potential benefits. Table 10 shows how the examined benefits in this study contribute to the 13 critical success factors for implementing supply chain management identified by (Kumar et al., 2015). As shown in Table 10, IoT adoption contributes to the different critical success factors as following; higher flexibly in production system ( 5 contributors); effective information sharing with supply chain members (4 contributors); focus on core strengths (4 contributors); development of effective supply chain management strategies (3 contributors); use of modern technologies (3 contributors); devoted resources for supply chain (3 contributors); forecasting of demand on point-of sale ( 2 contributors); development of reliable suppliers ( 2 contributors); focus on core strengths ( 2 contributors); and logistics synchronization ( 1 contributor).

Table 10 loT adoption impact on key SCM Critical Success Factors 


\begin{tabular}{|c|c|c|}
\hline & Critical Success Factor & IoT adoption impact on the Critical Success Factor \\
\hline 1 & Top management commitment & $\mathrm{N} / \mathrm{A}$ \\
\hline 2 & $\begin{array}{l}\text { Development of effective } \\
\text { supply chain management } \\
\text { strategy }\end{array}$ & $\begin{array}{l}\text { Procurement strategies optimization in product recovery operations, i.e. } \\
\text { acquisition mgmt. for end-of-use products } \\
\text { Improve management resolution by involving additional elements within } \\
\text { SC operational processes } \\
\text { - Supply Chains will start to act in a predictable manner instead of reacting } \\
\text { to the market needs }\end{array}$ \\
\hline 3 & $\begin{array}{l}\text { Devoted resources for supply } \\
\text { chain }\end{array}$ & $\begin{array}{l}\text { - } \quad \text { Improved fleet and transportation management } \\
\text { - } \quad \text { Better proactive replenishment of material } \\
\text { - } \quad \text { Reduction of inventory levels throughout SC nodes }\end{array}$ \\
\hline 4 & Logistics synchronization & - Transparency from local and international logistics operations \\
\hline 5 & Use of modern technologies & $\begin{array}{l}\text { - A disruptive technology that will reshape models of SCM considering } \\
\text { autonomous parts from a digitalized value chain with electronic network } \\
\text { of activities } \\
\text { - Emerging of innovative operational architectures with analytical } \\
\text { approaches and collaborative win-win model } \\
\text { Better support to e-commerce platforms through reliability and } \\
\text { availability in information }\end{array}$ \\
\hline 6 & $\begin{array}{l}\text { Information sharing with supply } \\
\text { chain members }\end{array}$ & $\begin{array}{l}\text { - More transparency and visibility of information and material flows } \\
\text { Better support to e-commerce platforms through reliability and } \\
\text { availability in information } \\
\text { Production adjustments based on real-time information of the demand } \\
\text { and capacity availability } \\
\text { Development of reliability, responsiveness and agility through fast } \\
\text { exchange of real-time information and facilitating process activities } \\
\text { improvements }\end{array}$ \\
\hline 7 & $\begin{array}{l}\text { Forecasting of demand on } \\
\text { point-of-sale (POS) }\end{array}$ & $\begin{array}{l}\text { - Production adjustments based on real-time information of the demand } \\
\text { and capacity availability } \\
\text { - } \quad \text { Enhancement the real-time visibility of demand and capacity fluctuations }\end{array}$ \\
\hline 8 & $\begin{array}{l}\text { Trust development in supply } \\
\text { chain partners }\end{array}$ & $\begin{array}{l}\text { Improvement in the control and management of SC foot print to ensure } \\
\text { regulation compliance. }\end{array}$ \\
\hline 9 & $\begin{array}{l}\text { Developing Just-in-time } \\
\text { capabilities }\end{array}$ & $\begin{array}{l}\text { - Improvement in Just-in-Time manufacturing through better production } \\
\text { scheduling }\end{array}$ \\
\hline 10 & $\begin{array}{l}\text { Development of reliable } \\
\text { suppliers }\end{array}$ & $\begin{array}{l}\text { Development of reliability, responsiveness and agility through fast } \\
\text { exchange of real-time information and facilitating process activities } \\
\text { improvements } \\
\text { Decentralization of decisions - computing power and processing time can } \\
\text { be redirected to critical areas along the SC network based on availability } \\
\text { and reliability of real-time data. }\end{array}$ \\
\hline 11 & $\begin{array}{l}\text { Higher flexibility in production } \\
\text { system }\end{array}$ & $\begin{array}{l}\text { - Production adjustments based on real-time information of the demand } \\
\text { and capacity availability } \\
\text { - } \quad \text { Production process optimization by detecting conflicts and inefficiencies } \\
\text { - } \text { Prediction of optimal level of production by reducing overproduction and } \\
\text { - } \quad \text { cost saving during production process in raw material, energy, water, } \\
\text { human, machine, equipment. } \\
\text { Improvement in Just-in-Time manufacturing through better production } \\
\text { scheduling }\end{array}$ \\
\hline 12 & Focus on core strengths & $\begin{array}{l}\text { - } \quad \text { Development of operational efficiency } \\
\text { - } \quad \text { Improved products tracking and traceability } \\
\text { - } \quad \text { Better control and management of inventories } \\
\text { Improvement in company assets utilization, reduction in machinery loss } \\
\text { and downtimes }\end{array}$ \\
\hline 13 & $\begin{array}{l}\text { Long-term vision for survival } \\
\text { and growth }\end{array}$ & $\begin{array}{l}\text { - Cost saving during production process in raw material, energy, water, } \\
\text { human, machine, equipment. }\end{array}$ \\
\hline
\end{tabular}


On the other hand, the examined 30 potential challenges associated with IoT adoption can be categorized into the groups. As show in Table 11, the majority of challenges and risks are associated with technical aspects of the IoT technology e.g. installation and operational. The second category includes the organizational challenges. These are related to current business environments and the need to embrace the new way of doing things when IoT is adopted. The remaining challenges were related to available resources needed to acquire IoT needed technologies. It is recommended that organizations assess their current organizational and technological environments and determine what should be done differently in order to be ready to adopt IoT. Overcoming any potential challenge or risks in advance is also strongly recommended.

Table 11 loT adoption challenges and their sources

\begin{tabular}{|c|c|}
\hline Challenge category & Challenge source \\
\hline $\begin{array}{l}\text { Technological } \\
\text { challenges }\end{array}$ & 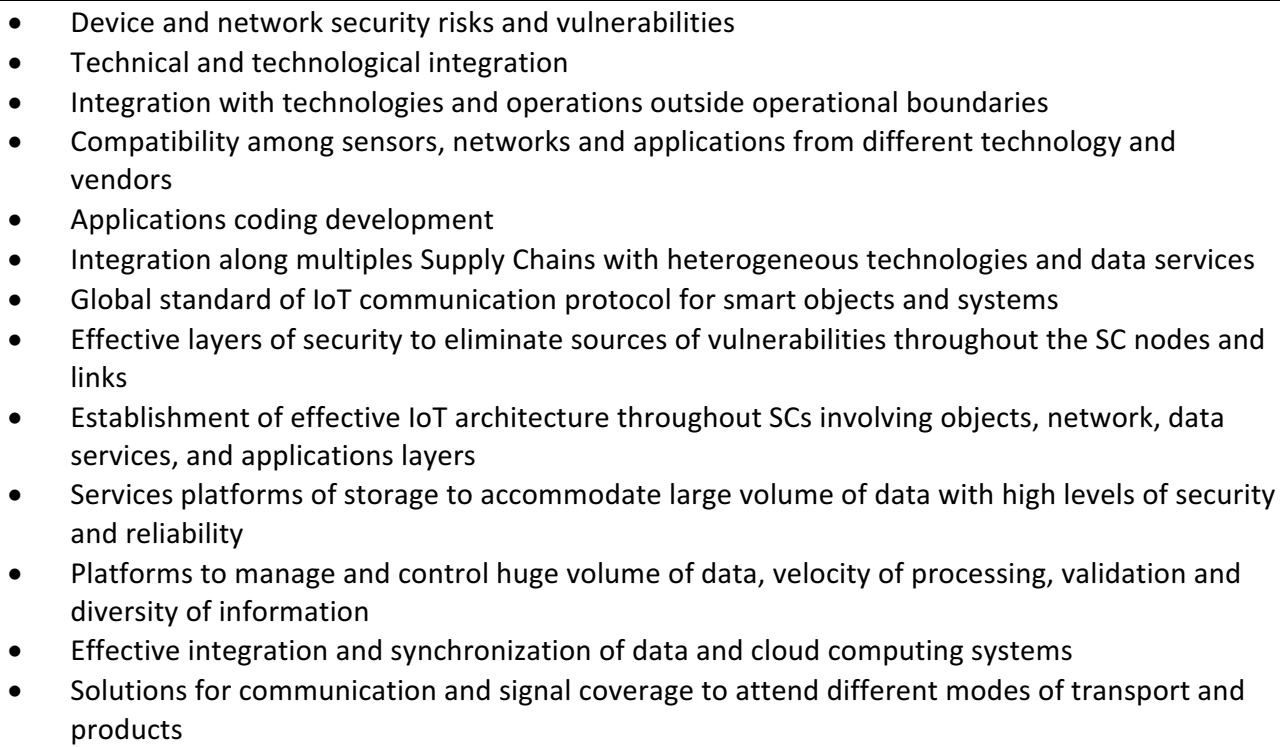 \\
\hline $\begin{array}{l}\text { Organizational } \\
\text { challenges }\end{array}$ & $\begin{array}{l}\text { - } \quad \text { Lack of a clear comprehension about the loT benefits } \\
\text { - } \quad \text { Risks associated with implementation of new business model } \\
\text { - } \quad \text { Loss of privacy, trust, confidentiality and availability risks } \\
\text { - } \quad \text { Seamployees' resistance to new technologies and practices } \\
\text { cyberspace } \\
\text { - } \quad \text { Avoidance of malicious and unintentional security incidents involving employees, contractors } \\
\text { and vendors } \\
\text { - } \quad \text { Displacement of human resources } \\
\text { - } \quad \text { Identification of the economic model that will define and capture the business value for the } \\
\text { - } \quad \text { Denefit of SCM } \\
\text { - } \quad \text { Design of new SC business models to support the still unstructured firm-oriented ecosystems } \\
\text { - Challenge with Just-in-Time manufacturing regarding dynamic production scheduling }\end{array}$ \\
\hline $\begin{array}{l}\text { Resources } \\
\text { availability } \\
\text { challenges }\end{array}$ & $\begin{array}{l}\text { - } \quad \text { Challenges with obtaining the needed supporting staff with right skills and knowledge } \\
\text { - } \quad \text { Availability of financial resources to support implementation and maintenance } \\
\text { - } \quad \text { Financial investments from all participants to design and deploy loT technologies and solutions }\end{array}$ \\
\hline
\end{tabular}


It is important to mention that the significance/insignificance of the examined potential benefits and challenges have sometimes been confirmed with other studies' findings. However, these were different on several other occasions. We think that is because our data was collected from academics and some of the compared against studies used case studies and practitioners from the industry.

\subsection{Research theoretical contribution}

The contribution of this study lies in examining top benefits individual business and their entire supply chains can obtain from adopting IoT. The study has also examined top challenges individual organizations and entire supply chains may encounter when adopting IoT. The findings from this study can be considered a rich source of insights about IoT impact on supply chain management and what organizations should consider when implementing IoT solutions. This study provides starting points for the implementation of IoT in supply chains and it can also be used as a ground for future research endeavours that seeks to understand aspects related to business benefits from IoT adoption. Overall, the findings of this study fill some of the highlighted literature gap of related studies about IoT adoption and its potential (e.g. Borgia, 2014; Lee and Lee, 2015; Madakam et al., 2015; Mishra et al., 2016; Ng et al., 2015; Russo et al., 2015; Whitmore et al., 2014; Zhou et al., 2015).

\subsection{Managerial implications}

In addition to the discussed theoretical contributions, this study allows to draw conclusions relevant to IoT adoption for organisations and supply chains. Organisations remain hesitant about allocating the necessary resources to start embracing IoT projects. This low deployment of IoT solutions at a worldwide level is a result of; doubts about gained benefits, uncertain financial, social, and technical dimensions associated with such deployment and remain major obstacles to its wider acceptance and adoption by enterprises and supply chains participants. Therefore, this research attempted to generate valuable insights for IoT services and technology providers, professionals, and top management from both manufacturing and services industries. The findings from this study are particularly valuable for those businesses that are still waiting to embrace and deploy local initiatives regarding the use of innovative technologies of smart objects, cyber product systems, and data analytics from IoT solutions within their current operations. Our study provides support to top management to better understand business implications related to IoT adoption. Managers can be equipped with more holistic understanding of potential challenges related to IoT adoption that businesses are likely to face, internally and within their entire supply chains. Such understanding will enable them to better comprehend the top elements and factors that should be considered, and addressed in advance, within their initiatives, projects and designs of IoT applications. Furthermore, this will lead to making better strategic decisions about acquiring the suitable technologies, resources, and external support required for the IoT adoption. This will result in implementing best practices to fulfil their quest to optimize operational performance through better level of business competitiveness from acquiring innovative technological solutions. Furthermore, this study suggests that more managerial attention is paid to not just the selection of IoT technology to be implemented but also to the potential techno-organizational implications of such adoption for organizations and supply chains. The role of top management in IoT adoption is particularly crucial in determining the level of such adoption and ensuring required support, resources, and sponsorship are provided throughout the implementation phases. Our study can be a valuable source of relevant 
information for managers to develop, promote and defend the acceptance of IoT projects prior embarking on adoption journeys, during the implementation phases, and later during the operational stage, therefore promoting the leverage of current initiatives and success in the deployment of IoT solutions. As mentioned earlier, the authors believe that because the IoT technologies are still in the development process and its applications within different sectors is still expanding; the findings from our theoretical study based on academics views can be considered as a suitable guidance for practical implementations.

\subsection{Limitations and future research}

This research explored participants perceptions about a number of pre-determined potential benefits and challenges individual organizations and their entire supply chains are likely to encounter when adopting the IoT. Future research may explore benefits and challenges within organizations through the use of open-ended or multiple-choice survey questions. This may result in reporting different potential benefits and challenges that were not included in our study. Furthermore, this study examined potential benefits and challenges related to IoT adoption but it did not explore how best organizations should adopt IoT implementation within supply chains. Thus, further studies may look into this theme. Also, our study did not explore ways to overcome the examined challenges. In addition to exploring IoT adoption best practices, recommending how to overcome implementation hurdles would be another future research stream. Finally, this study was limited to individuals, mainly university scholars, who published academic papers in two professional international conferences and two relevant academic journals. The authors made this decision based on the assumption that the level of IoT implementation is still limited and it would be better to gather primary data from experts who have theoretical knowledge about the selected topic. Two of the selected venues were professional conferences and relevant scholarly journals. However, as time proceeds and perhaps more development of IoT solutions is embraced, we suggest that further research may consider capturing perceptions of participants from different industries. This will allow researchers to capture practical insights from practitioners and professionals who are likely to have direct involvement of IoT adoption and operation. Finally, every effort has been made to ensure data is

collected from a larger group but our study was based on the perceptions of 87 participants and it is strongly recommended that a larger sample is used.

\section{Acknowledgement}

\section{References}

Alaba, F, Othman, M, Hashem, I, \& Alotaibi, F 2017, 'Internet of Things security: A survey', Journal of Network \& Computer Applications, 88, pp. 10-28

Al-Fuqaha, A., Guizani, M., Mohammadi, M., Aledhari, M., and Ayyash, M. (2015), "Internet of things: A survey on enabling technologies, protocols, and applications". IEEE Communications Surveys and Tutorials, Vol. 17 No. 4, pp. 2347-2376.

Alghadeir, A., and Al-Sakran, H. (2016), "Smart airport architecture using Internet of Things". International Journal of Innovative Research in Computer Science \& Technology. Vol. 4 No. 5, pp. 148-155.

Agrawal, S., and Mazumdar, H. S. (2015), "Economic viability and Future Impact of Internet of Things in India: An Inevitable wave", arXiv preprint arXiv:1601.04363.

Atzori, L., Iera, A. and Morabito, G., 2010. The internet of things: A survey. Computer networks, 54(15), pp.2787-2805.

Avery, S. (2015) Procurement: Internet of Things Technology to Have Impact, My Purchasing Center.Available 
from: http://www.mypurchasingcenter.com/technology/technology-articles/procurement-internet-thingstechnologies-have-impact/(accessed 30 March 2017).

Behrendt, A., Müller, N., Odenwälder, P., and Christoph Schmitz, C. (2017, March), "Industry 4.0 demystifiedlean's next level". Available at: http://www.mckinsey.com/business-functions/operations/ourinsights/industry-4-0-demystified-leans-next-level (accessed 30 March 2017).

$\mathrm{Bi}, \mathrm{Z}$. , Da Xu, L. and Wang, C., 2014. Internet of things for enterprise systems of modern manufacturing. IEEE Transactions on industrial informatics, 10(2), pp.1537-1546.

Biswas, S. \& Sen, J. (2016) “A Proposed Framework of Next Generation Supply Chain Management Using Big Data Analytics", Proceedings of National Conference on Emerging Trends in Business and Management: Issues and Challenges, Kolkata, INDIA.

Bok, B. (2016), "Innovating the retail industry: an IoT approach", in 7th IBA Bachelor Thesis Conference, 2016, Enschede, The Netherlands, pp: 1-17.

Borgia, E. (2014), "The Internet of Things vision: Key features, applications and open issues", Computer Communications, Vol. 54, pp. 1-31.

Botta, A., De Donato, W., Persico, V., and Pescapé, A. (2014, August). On the integration of cloud computing and Internet of Things. In proceedings of the $2^{\text {nd }}$ international conference on future internet of things and cloud (FiCloud - 2014), Barcelona, Spain : pp. 23-30.

Bröring, A., Schmid, S., Schindhelm, C.K., Khelil, A., Käbisch, S., Kramer, D., Le Phuoc, D., Mitic, J., Anicic, D. and Teniente, E., 2017. Enabling IoT ecosystems through platform interoperability. IEEE software, 34(1), pp.54-61.

Bughin, J., Chui, M. and Manyika, J., 2015. An executive's guide to the Internet of Things. McKinsey Quarterly, McKinsey\&Company, 2(9), pp.89-105.

Buntz, B (2015) Top 10 Reasons People Aren't Embracing the IoT. Internet of Things Institute. Available from: http://www.ioti.com/iot-trends-and-analysis/top-10-reasons-people-aren-t-embracing-iot. (accessed 20 May 2017).

Cao, Y., Li, W., Song, W. and Chaovalitwongse, W.A., 2013, June. Collaborative material and production tracking in toy manufacturing. In Computer Supported Cooperative Work in Design (CSCWD), 2013 IEEE 17th International Conference on (pp. 645-650). IEEE.

Chan, H.C., 2015. Internet of things business models. Journal of Service Science and Management, 8(4), p.552.

Chandrakanth, S., Venkatesh, K., Uma Mahesh, J., and Naganjaneyulu, K. V. (2014), "Internet of Things". International Journal of Innovations \& Advancement in Computer Science, Vol. 3 No. 8, pp. 16-20.

Chase Jr, C. W. (2016), "The digital revolution is changing the supply chain landscape". The Journal of Business Forecasting, Vol. 35 No. 2, pp. 20-22.

Chong, A. Y. L., Ooi, K. B., Lin, B., and Tang, S. Y. (2009), "Influence of interorganizational relationships on SMEs'e-business adoption". Internet Research: Electronic Networking Applications and Policy, Vol. 19 No. 3, pp. 313-331.

Cohen, J., Cohen, P., West, S.G. and Aiken, L.S. (2003), Applied Multiple Regression/Correlation Analysis for the Behavioral Sciences, 3rd ed., Lawrence Erlbaum Associates, London.

Cottong, S. (2016) Digital Transformation in business and society. Available from: https://www.luxorr.lu/e-download/actualite-tendances-2016-11-23-.pdf. (accessed 30 March 2017).

Costa, C, Antonucci, F, Pallottino, F, Aguzzi, J, Sarria, D, \& Menesatti, P. (2012) 'A Review on Agri-food Supply Chain Traceability by Means of RFID Technology', Food and Bioprocess Technology, 6, 2, pp. 353-366

$\mathrm{Da} \mathrm{Xu}, \mathrm{L} ., \mathrm{He}, \mathrm{W}$., and Li, S. (2014), "Internet of things in industries: A survey". IEEE Transactions on industrial informatics, Vol. 10 No. 4, pp. 2233-2243.

DeVellis, R.F. (1991), Scale Development: Theory and Applications, Sage Publications, Newbury Park, CA.

Dijkman, R.M., Sprenkels, B., Peeters, T. and Janssen, A., 2015. Business models for the Internet of Things. International Journal of Information Management, 35(6), pp.672-678.

Dweekat, A.J., Dweekat, A.J., Hwang, G., Hwang, G., Park, J. and Park, J., 2017. A supply chain performance measurement approach using the internet of things: Toward more practical SCPMS. Industrial Management \& Data Systems, 117(2), pp.267-286.

Dweekat, A.J. and Park, J., 2016, May. Internet of Things-Enabled Supply Chain Performance Measurement Model. In Industrial Engineering, Management Science and Application (ICIMSA), 2016 International Conference on (pp. 1-3). IEEE.

Ericsson (2015) Every. Thing. Connected - A study of the adoption of 'Internet of Things' among Danish 
companies. Available from:

http://digital.di.dk/SiteCollectionDocuments/Analyser/IoT Report onlineversion.pdf. (accessed on 25 May 2017)

Fan, T., Tao, F., Deng, S. and Li, S., 2015. Impact of RFID technology on supply chain decisions with inventory inaccuracies. International Journal of Production Economics, 159, pp.117-125.

Fang, C., Liu, X., Pardalos, P.M. and Pei, J., 2016. Optimization for a three-stage production system in the Internet of Things: procurement, production and product recovery, and acquisition. The International Journal of Advanced Manufacturing Technology, 83(5-8), pp.689-710.

Farahani, P., Meier, C., and Wilke, J. (2017), "Digital supply chain management agenda for the automotive supplier industry”. In Shaping the Digital Enterprise, Springer International Publishing, pp. 157-172.

Ferretti, M. and Schiavone, F., 2016. Internet of Things and business processes redesign in seaports: The case of Hamburg. Business Process Management Journal, 22(2), pp.271-284.

Fleisch, E., Weinberger, M. and Wortmann, F., 2014. Geschäftsmodelle im Internet der Dinge. HMD Praxis der Wirtschaftsinformatik, 51(6), pp.812-826.

Gartner, Inc. (2016, January), "Gartner says by 2020, more than half of major new business processes and systems will incorporate some element of the Internet of Things", available at: http://www.gartner.com/newsroom/id/3185623 (accessed 30 March 2017).

Gartner Press Release (2016), “Top 10 Internet of things technologies for 2017 and 2018”. Available at: http://www.gartner.com/newsroom/id/3221818 (accessed 3 April 2017).

Geerts, G. L., and O'Leary, D. E. (2014), "A supply chain of things: The EAGLET ontology for highly visible supply chains". Decision Support Systems, Vol. 63 No. 1, pp. 3-22.

Gerpott, T.J. and May, S., 2016. Integration of Internet of Things components into a firm's offering portfolio-A business development framework. info, 18(2), pp.53-63.

Ghashghaee, P., 2016. Smart manufacturing: role of Internet of Things in process optimization. Available from: https://dspace.cc.tut.fi/dpub/handle/123456789/24097. (accessed 22 May 2017).

Gliem, J. and Gliem, R. (2003). Calculating, Interpreting, and Reporting Cronbach's Alpha Reliability Coefficient for Likert-Type Scales. In 2003 Midwest Research to Practice Conference in Adult, Continuing and Community Education. Columbus, $\mathrm{OH}$.

Gnimpieba, Z, Nait-Sidi-Moh, A, Durand, D, \& Fortin, J 2015, 'Using Internet of Things Technologies for a Collaborative Supply Chain: Application to Tracking of Pallets and Containers', Procedia Computer Science, 56

Gregory, J. (2015), "The Internet of Things: revolutionizing the retail industry", available at: https://www.accenture.com/ acnmedia/Accenture/ConversionAssets/DotCom/Documents/Global/PDF/Dua lpub 14/Accenture-The-Internet-Of-Things.pdf\#zoom=50 (accessed 30 March 2017).

Gubbi, J., Buyya, R., Marusic, S., and Palaniswami, M. (2013), "Internet of Things (IoT): A vision, architectural elements, and future directions". Future generation computer systems, Vol. 29 No. 7, pp. 1645-1660.

$\mathrm{He}, \mathrm{W}$. and $\mathrm{Da} \mathrm{Xu}, \mathrm{L} ., 2$ 2014. Integration of distributed enterprise applications: A survey. IEEE Transactions on Industrial Informatics, 10(1), pp.35-42.

Hair, Jr., J. F., Black, W. C., Babin, B. J., Anderson, R. E., and Tatham, R. L. (2006). Multivariate Data Analysis (6th ed.). Upper Saddle River, NJ: Pearson Prentice Hall.

Hinkin, T. R. (1995), "A review of scale development practices in the study of organizations". Journal of management, Vol. 21 No. 5, pp. 967-988.

Hognelid, P. \& Kalling, T. (2015) 'Internet of Things and Business Models' 2015, 2015 IEEE 9Th International Conference On Standardization And Innovation In Information Technology (SIIT), Standardization And Innovation In Information Technology (SIIT), 2015 IEEE 9Th International Conference On, p. 1

Hung, M. (2016) Special Report - IoT's Challenges and Opportunities in 2017. Available from: http://www.gartner.com/technology/research/internet-of-things/report/?cm sp=sr- -iot- -link (accessed on 25 May 2017)

Hussain, M 2017, 'Internet of Things: challenges and research opportunities', CSI Transactions On ICT, 5, 1, p. 87, Supplemental Index, EBSCOhost, viewed 22 May 2017.

Intel (2017) IoT Solutions Across Industries - Case Studies. Available from: http://www.intel.com/content/www/us/en/internet-of-things/solution-blueprints-and-case-studies.html (accessed 24 May 2017).

Jin, J., Gubbi, J., Marusic, S. and Palaniswami, M., 2014. An information framework for creating a smart city through internet of things. IEEE Internet of Things Journal, 1(2), pp.112-121.

Kang, K., Qu, T., Nie, D.X., Zhang, T., Wang, Z.Z. and Huang, G.Q., 2016, April. Production system multi-stage 
synchronization based on collaborative optimization under the Internet-of-Things environment. In Networking, Sensing, and Control (ICNSC), 2016 IEEE 13th International Conference on (pp. 1-6). IEEE.

Kambies, T., Raynor, M., Pankratz, D., and Wadekar, G. (2016), "Closing the digital divide: IoT in retail's transformative potential", available at: http://dupress.com/articles/internet-of-things-iot-retail-strategies/ (accessed 30 March 2017).

Kerravala, Z. (2017) 10 enterprise Internet of Things deployments with actual results. Networkworld from IDG. Available from: http://www.networkworld.com/article/2848714/cisco-subnet/10-enterprise-internet-ofthings-deployments-with-actual-results.html (accessed 24 May 2017).

Khan, R., Khan, S. U., Zaheer, R., and Khan, S. (2012, December), "Future Internet: the Internet of things architecture, possible applications and key challenges", in proceedings of the $10^{\text {th }}$ internal conference on frontiers of information technology (FIT), in Islamabad, Pakistan, 2012, pp: 257-260.

Kiritsis, D., 2011. Closed-loop PLM for intelligent products in the era of the Internet of things. Computer-Aided Design, 43(5), pp.479-501.

Klötzer, C., and Pflaum, A. (2017, January), "Toward the development of a maturity model for digitalization within the manufacturing industry's supply chain", in proceedings of the 50th Hawaii international conference on system sciences, Hawaii, U.S, 2017, pp: 4210 - 4219.

Koenig, K., Lanzilotta, C., LaValle, S., Pande, R., and Vaidya, M. (2016), "The Internet of Things in insurance: shaping the right strategy, mapping the biggest risks", available at: http://www.ey.com/Publication/vwLUAssets/EY - The internet of things in insurance/\$FILE/EY-theinternet-of-things-in-insurance.pdf (accessed 30 March 2017).

Korpela, K., Hallikas, J., and Dahlberg, T. (2017, January), "Digital Supply Chain Transformation toward Blockchain Integration", in proceedings of the 50th Hawaii international conference on system sciences, Hawaii, U.S, 2017, pp: 4182-4191.

Kulkarni, A., and Sathe, S. (2014), "Healthcare applications of the Internet of Things: A Review". International Journal of Computer Science and Information Technologies, Vol. 5 No. 5, pp. 6229-32.

Kumar, R., Singh, R. K., and Shankar, R. (2015), "Critical success factors for implementation of supply chain management in Indian small and medium enterprises and their impact on performance". IIMB Management Review, Vol. 27 No. 2, pp. 92-104.

Kumar, V., Amorim, M., Bhattacharya, A. and Garza-Reyes, J.A., 2016. Managing reverse exchanges in service supply chains. Supply Chain Management: An International Journal, 21(2), pp.157-165.

Kyriazis, D., Varvarigou, T., White, D., Rossi, A., and Cooper, J. (2013, June), "Sustainable smart city IoT applications: Heat and electricity management \& Eco-conscious cruise control for public transportation", in proceedings of $14^{\text {th }}$ international symposium and workshops world of wireless, mobile and multimedia networks (WoWMoM), 2013, Madrid, Spain, pp: 1-5.

Lee, I., 2016. An Exploratory Study of the Impact of the Internet of Things (IoT) on Business Model Innovation: Building Smart Enterprises at Fortune 500 Companies. International Journal of Information Systems and Social Change (IJISSC), 7(3), pp.1-15.

Lee, I., and Lee, K. (2015), "The Internet of Things (IoT): Applications, investments, and challenges for enterprises". Business Horizons, Vol. 58 No. 4, pp. 431-440.

Li, S., Da Xu, L. and Zhao, S., 2015. The internet of things: a survey. Information Systems Frontiers, 17(2), pp.243259.

Li, B., and Li, Y. (2017), "Internet of Things drives supply chain innovation: a research framework". International Journal of Organizational Innovation, Vol. 9 No. 3, 71B.

Lightwell (2014) How the Internet of Things will reshape supply chain management. Available from: http://info.lightwellinc.com/blog/bid/166203/How-the-Internet-of-Things-will-reshape-supply-chainmanagement (accessed 22 May 2015).

Lo, V. H., and Yeung, A. (2006), "Managing quality effectively in supply chain: a preliminary study". Supply Chain Management: An International Journal, Vol. 11 No. 3, pp. 208-215.

Lund, D., MacGillivray, C., Turner, V., and Morales, M. (2014), "Worldwide and regional internet of things (IoT) 2014-2020 forecast: A virtuous circle of proven value and demand", available at: https://www.business.att.com/content/article/IoT-worldwide regional 2014-2020-forecast.pdf (accessed 30 March 2017).

Macaulay, J., Buckalew, L. and Chung, G. (2015), “Internet of things in logistics”, Troisdorf, available at: www.dpdhl.com/content/dam/dpdhl/presse/pdf/2015/DHLTrendReport Internet of things.pdf (accessed 16 May 2015)

Madakam, S., Ramaswamy, R., and Tripathi, S. (2015), "Internet of Things (IoT): A literature review". Journal of 
Computer and Communications, Vol. 3 No. 5, pp. 164-173.

Majeed, A.A. and Rupasinghe, T.D., 2017. Internet of Things (IoT) Embedded Future Supply Chains for Industry 4.0: An Assessment from an ERP-based Fashion Apparel and Footwear Industry. International Journal of Supply Chain Management, 6(1), pp.25-40.

Maksimović, M., Vujović, V., and Periśić, B. (2015, June), “A custom Internet of Things healthcare system”, in proceedings of the $10^{\text {th }}$ Iberian conference on information systems and technologies (CISTI), 2015, At Águeda, Portuga, pp: 1-6.

Mann, J., 2015. The Internet of Things: Opportunities and applications across industries. International Institute for Analytics, Enterprise Research Service, December.

Meier C (2014), "Digital supply chain management", in Uhl A, Gollenia LA (Ed.), Digital enterprise transformation. A business-driven approach to leveraging innovative IT. Routledge, London

Michaelides, Z., 2016. Big data for logistics and supply chain management. In Production and Operations Management Society (POMS) Conference Proceedings in Orlando, Florida.

Mishra, D., Gunasekaran, A., Childe, S. J., Papadopoulos, T., Dubey, R., and Wamba, S. (2016), "Vision, applications and future challenges of Internet of Things: A bibliometric study of the recent literature". Industrial Management \& Data Systems, Vol. 11 No. 7, pp. 1331-1355.

Moreno, M., Úbeda, B., Skarmeta, A. F., and Zamora, M. A. (2014), "How can we tackle energy efficiency in IoT based smart buildings?”. Sensors, Vol. 14 No. 6, pp. 9582-9614.

Natarajan, K., Prasath, B., and Kokila, P. (2016), "Smart health care system using Internet of Things", Journal of Network Communications and Emerging Technologies, Vol. 6 No. 3, pp. 37-42.

Ng, I., Scharf, K., Pogrebna, G., and Maull, R. (2015), "Contextual variety, Internet-of-Things and the choice of tailoring over platform: Mass customisation strategy in supply chain management". International Journal of Production Economics, Vol. 159 No. , pp. 76-87.

O'Halloran, D. and Kvochko, E., 2015. Industrial Internet of Things: Unleashing the Potential of Connected Products and Services. In World Economic Forum (p. 40).

O'Leary-Kelly, S. W., and Vokurka, R. J. (1998), "The empirical assessment of construct validity". Journal of operations management, Vol. 16 No. 4, pp. 387-405.

O'Marah, K. (2015) The Internet of Things Will Make Manufacturing Smarter. IndustryWeek. Available from: http://www.industryweek.com/manufacturing-smarter (accessed 22 May 2017).

Ondemir, O. and Gupta, S.M., 2014. Quality management in product recovery using the Internet of Things: An optimization approach. Computers in Industry, 65(3), pp.491-504.

Pang, Z., Chen, Q., Han, W. and Zheng, L., 2015. Value-centric design of the internet-of-things solution for food supply chain: value creation, sensor portfolio and information fusion. Information Systems Frontiers, 17(2), pp.289-319.

Pfisterer, D, Radonjic-Simic, M, \& Reichwald, J 2016, 'Business Model Design and Architecture for the Internet of Everything', Journal of Sensor \& Actuator Networks, 5, 2, pp. 1-21

Pflaum, A., Bodendorf, F., Prockl, G., and Chen, H. (2017), "Introduction to the digital supply chain of the future: technologies, applications and business models minitrack in proceedings of the 50th Hawaii international conference on system sciences, Hawaii, U.S., 2017, pp: 4179-4181.

Reaidy, P.J., Gunasekaran, A. and Spalanzani, A., 2015. Bottom-up approach based on internet of things for order fulfillment in a collaborative warehousing environment. International Journal of Production Economics, 159, pp.29-40.

Riggins, F.J. and Wamba, S.F., 2015, January. Research directions on the adoption, usage, and impact of the internet of things through the use of big data analytics. In System Sciences (HICSS), 2015 48th Hawaii International Conference on (pp. 1531-1540). IEEE.

Rivard, S., and Huff, S. L. (1988), "Factors of success for end-user computing". Communications of the ACM, Vol. 31 No. 5, pp. 552-561.

Roblek, V., Meško, M., and Krapež, A. (2016), “A Complex View of Industry 4.0”. SAGE Open, Vol. 6 No. 2, pp. $1-11$.

Robinson, A. (2015), “The future of supply chain, logistics \& manufacturing: how technology is transforming industries". Available at: http://cerasis.com/wpcontent/uploads/2015/12/Technology Manufacturing SupplyChain Logistics eBook.pdf (accessed 31 March 2017).

Russo, G., Marsigalia, B., Evangelista, F., Palmaccio, M., and Maggioni, M. (2015), "Exploring regulations and scope of the Internet of Things in contemporary companies: a first literature analysis". Journal of Innovation and Entrepreneurship, Vol. 4 No. 1, pp. 1-13. 
Ryan, P.J. and Watson, R.B., 2017. Research Challenges for the Internet of Things: What Role Can OR Play? Systems, 5(1), p.24.

Rymaszewska, A., Helo, P. and Gunasekaran, A., 2017. IoT powered servitization of manufacturing-an exploratory case study. International Journal of Production Economics

Santos, J. R. A. (1999), "Cronbach's alpha: A tool for assessing the reliability of scales". Journal of extension, Vol. 37 No. 2, pp. 1-5.

SAP Corporation (2014), "CEO Perspective: The Internet of Things for Utilities", available at: https://www.sap.com/bin/sapcom/ko kr/downloadasset.2014-10-oct-28-03.ceo-perspective-the-internet-ofthings-for-utilities-pdf.html (accessed 04 April 2017).

Schimek, R.S. (2017) IoT Case Studies: Companies Leading the Connected Economy. American International Group. Available from: https://www.aig.com/content/dam/aig/america-canada/us/documents/brochure/iotcase-studies-companies-leading-the-connected-economy-digital-report.pdf (accessed 24 May 2017).

Schrauf, S., and Berttram, P. (2016), "How digitization makes the supply chain more efficient, agile and customerfocused", available at: http://www.strategyand.pwc.com/media/file/Industry4.0.pdf (accessed 30 March 2017).

Selinger, M., Sepulveda, A., and Buchan, J. (2013). Education and the Internet of Everything: How ubiquitous connectedness can help transform pedagogy. White Paper, Cisco, San Jose, CA, Oct.

Sun, C., 2012. Application of RFID technology for logistics on internet of things. AASRI Procedia, 1, pp.106-111.

Tao, F., Cheng, Y., Da Xu, L., Zhang, L. and Li, B.H., 2014. CCIoT-CMfg: cloud computing and internet of thingsbased cloud manufacturing service system. IEEE Transactions on Industrial Informatics, 10(2), pp.14351442 .

Tan, J. and Koo, S.G., 2014, May. A survey of technologies in internet of things. In Distributed Computing in Sensor Systems (DCOSS), 2014 IEEE International Conference on (pp. 269-274). IEEE.

Tavakol, M. and Dennick, R., 2011. Making sense of Cronbach's alpha. International journal of medical education, 2, pp.51-53.

Thiesse, F. and Buckel, T., 2015. A comparison of RFID-based shelf replenishment policies in retail stores under suboptimal read rates. International Journal of Production Economics, 159, pp.126-136.

Ting, S.L., Kwok, S.K., Albert, H.T. and Lee, W.B., 2010, October. Enhancing the information transmission for pharmaceutical supply chain based on Radio Frequency Identification (RFID) and Internet of Things. In Supply Chain Management and Information Systems (SCMIS), 2010 8th International Conference on (pp. 1-5). IEEE.

Tracy P. (2017) The top 5 industrial IoT use cases. Available from: https://www.ibm.com/blogs/internet-of-things/top-5-industrial-iot-use-cases/ (accessed 24 May 2017).

Turunen, J. (2017) IoT Product Development. Available from: https://managementevents.com/news/iot-product-development/ (accessed 24 May 2017).

Uckelmann, D., Harrison, M. and Michahelles, F., 2011. An architectural approach towards the future internet of things. In Architecting the internet of things (pp. 1-24). Springer Berlin Heidelberg.

Uddin, S. and Al Sharif, A.A., 2016, December. Integrating Internet of Things with maintenance spare parts' supply chain. In Electronic Devices, Systems and Applications (ICEDSA), 2016 th International Conference on (pp. 1-4). IEEE.

Valmohammadi, C., 2016. Examining the perception of Iranian organizations on Internet of Things solutions and applications. Industrial and Commercial Training, 48(2), pp.104-108.

Velandia, D. M. S., Kaur, N., Whittow, W. G., Conway, P. P., and West, A. A. (2016), "Towards industrial Internet of Things: Crankshaft monitoring, traceability and tracking using RFID”. Robotics and ComputerIntegrated Manufacturing, Vol. 41, pp. 66-77.

Vermesan, O., Friess, P., Guillemin, P., Gusmeroli, S., Sundmaeker, H., Bassi, A., Jubert, I.S., Mazura, M., Harrison, M., Eisenhauer, M. and Doody, P., 2011. Internet of things strategic research roadmap. Internet of Things-Global Technological and Societal Trends, 1, pp.9-52.

Wagenaar, J. (2012) 'The impact of the Internet of Things on revenue in supply chains', Available on: http://referaat.cs.utwente.nl/conference/17/paper/7328/the-impact-of-the-internet-of-things-on-revenue-insupply-chains.pdf (accessed 24 May 2017).

Westerbeek, D. (2016) The Internet of Things as a source for improving the product development process. Available from: http://essay.utwente.nl/69966/ (accessed 24 May 2017).

Whitmore, A., Agarwal, A., and Da Xu, L. (2015), "The Internet of Things-A survey of topics and trends". Information Systems Frontiers, Vol. 17 No. 2, pp. 261-274. 
Wortmann, F., and Flüchter, K. (2015), "Internet of Things”. Business \& Information Systems Engineering, Vol. 57 No. 3, pp. 221-224.

Wu, L., Yue, X., Jin, A., and Yen, D. C. (2016), "Smart supply chain management: a review and implications for future research". The International Journal of Logistics Management, Vol. 27 No. 2, pp. 395-417.

$\mathrm{Xu}$, L.D., 2011. Information architecture for supply chain quality management. International Journal of Production Research, 49(1), pp.183-198.

Xu, Z., He, J. and Chen, Z., 2012, December. Design and actualization of IoT-based intelligent logistics system. In Industrial Engineering and Engineering Management (IEEM), 2012 IEEE International Conference on (pp. 2245-2248). IEEE.

Yan, J., Xin, S., Liu, Q., Xu, W., Yang, L., Fan, L., Chen, B., and Wang, Q. (2014), "Intelligent supply chain integration and management based on cloud of things". International Journal of Distributed Sensor Networks, Vol. 10 No. 3, pp. 1-15.

Yan, R. and Yan, R., 2017. Optimization approach for increasing revenue of perishable product supply chain with the Internet of Things. Industrial Management \& Data Systems, 117(4), pp.729-741.

Yan, Z., Zhang, P. and Vasilakos, A.V., 2014. A survey on trust management for Internet of Things. Journal of network and computer applications, 42, pp.120-134.

Yu, Q., and Wang, K. (2016), “Applications of IoT in production logistics: Opportunities and challenges”. WIT Transactions on Engineering Sciences, Vol. 113, pp. 233-240.

Zheng, D., and Carter, W. A. (2015). Leveraging the internet of things for a more efficient and effective military. Rowman \& Littlefield.

Zhong, R.Y., Newman, S.T., Huang, G.Q. and Lan, S., 2016. Big Data for supply chain management in the service and manufacturing sectors: Challenges, opportunities, and future perspectives. Computers \& Industrial Engineering, 101, pp.572-591.

Zhou, L., Chong, A. Y., and Ngai, E. W. (2015), "Supply chain management in the era of the Internet of Things", International Journal of Production Economics, Vol. 159, pp. 1-3.

Zhou, Z., Liu, X., Pei, J., Pardalos, P.M., Liu, L. and Fu, C., 2016. Real options approach to explore the effect of organizational change on IoT development project. Optimization Letters, pp.1-17. 